\title{
Archaeological Testing at Rancho de las Cabras, 41WN30, Wilson County, Texas, Second Season
}

James E. Ivey

Follow this and additional works at: https://scholarworks.sfasu.edu/ita

Part of the American Material Culture Commons, Archaeological Anthropology Commons, Environmental Studies Commons, Other American Studies Commons, Other Arts and Humanities Commons, Other History of Art, Architecture, and Archaeology Commons, and the United States History Commons

Tell us how this article helped you.

This Article is brought to you for free and open access by the Center for Regional Heritage Research at SFA ScholarWorks. It has been accepted for inclusion in Index of Texas Archaeology: Open Access Gray Literature from the Lone Star State by an authorized editor of SFA ScholarWorks. For more information, please contact cdsscholarworks@sfasu.edu. 
Archaeological Testing at Rancho de las Cabras, 41WN30, Wilson County, Texas, Second Season

\section{Creative Commons License}

(c) (i) (8)

This work is licensed under a Creative Commons Attribution-NonCommercial 4.0 International License 


\section{ARCHAEOLOGICAL TESTING AT RANCHO DE LAS CABRAS, 41 WN 30, WILSON COUNTY, TEXAS SECOND SEASON}

James E. Ivey

With an Appendix by Joseph H. Labadie

CENTER FOR ARCHAEOLOGICAL RESEARCH THE UNIVERSITY OF TEXAS AT SAN ANTONIO ARCHAEOLOGICAL SURVEY REPORT, NO. 121 

ARCHAEOLOGICAL TESTING AT RANCHO DE LAS CABRAS, 41 WN 30, WILSON COUNTY, TEXAS. SECOND SEASON.

James E. Ivey

With an Appendix by

Joseph H. Labadie

Center for Archaeological Research The University of Texas at San Antonio Archaeological Survey Report, No. 121 
The following information is provided in accordance with General Rules of Practice and Procedure Chapter 41.11 (Investigation Reports), Texas Antiquities Committee:

1. Type of investigation: Historical, architectural, and archaeological investigations at the Rancho de las Cabras;

2. Project name: Rancho de las Cabras;

3. County: Wilson County, Texas;

4. Principal Investigator: Thomas R. Hester; Co-Principal Investigators: Jack D. Eaton and James E. Ivey; and Field Director: James E. Ivey;

5. Name and location of sponsoring agency: Texas Parks and Wildlife Department, Austin, Texas;

6. Texas Antiquities Committee Permit No. 281;

7. Published by the Center for Archaeological Research, The University of Texas at San Antonio, San Antonio, Texas 78285, 1983. 
TABLE OF CONTENTS

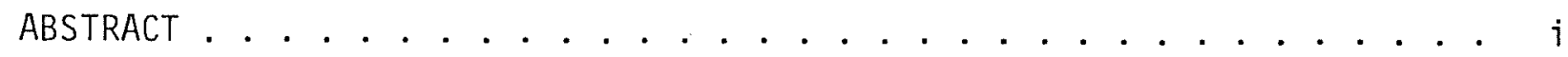

LIST OF FIGURES . . . . . . . . . . . . . . . . . . . . . iv

LIST OF TABLES .......................... . . . . . . . . . . . .

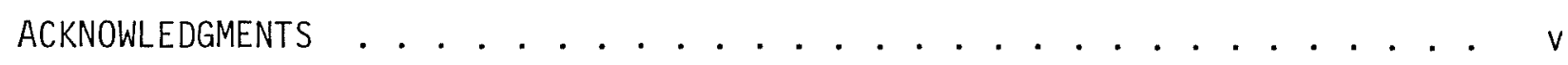

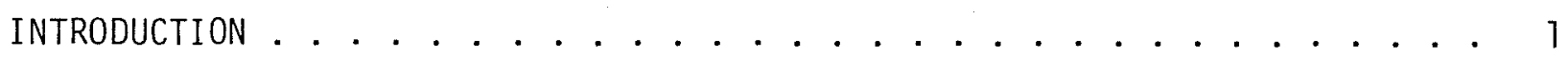

SCOPE OF WORK AND METHODOLOGY ....................... 2

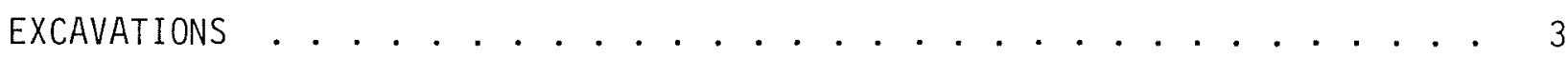

The Northeast Corner . . . . . . . . . . . . . . . 3

Unit $17 \ldots \ldots . \ldots . \ldots . . \ldots$

Unit $18 \ldots \ldots . . \ldots \ldots$

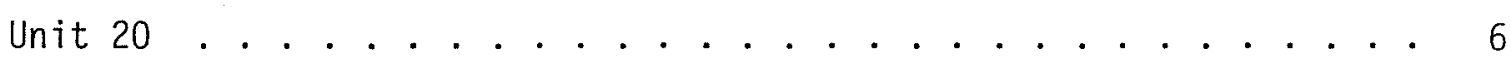

Unit 21 .................... 6

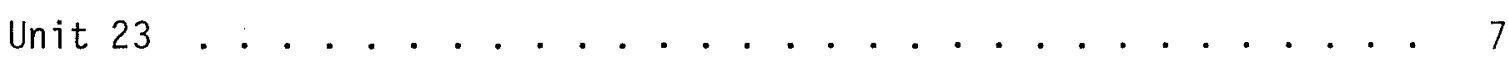

Bastions ................... . . 8

Unit 19 .................... 8

Unit $25 \ldots \ldots \ldots 8$

Southwestern Corner. . . . . . . . . . . . . . . . 9

The Northwestern Gateway . . . . . . . . . . . . . . . . 10

Trash Pits .................. 10

Area A...................... 12

ARTIFACT ANALYSIS ........................... 16

Discussion . . . . . . . . . . . . . . . . 23

HISTORY OF RANCHO DE LAS CABRAS . . . . . . . . . . . . . . . 24

Ranch Development in the 1770s ............ . . 29 


\section{ABSTRACT}

In the summer of 1981, the second season of excavations at the Rancho de las Cabras (41 WN 30) was conducted by the Center for Archaeological Research, The University of Texas at San Antonio, for the Texas Parks and Wildlife Department, Austin, Texas. This season included further architectural testing and stratigraphic excavations in a large trash pit located during season one, July 1980. A five by six meter area of the interior northwest corner was excavated revealing wall trenches and floors of part of a jacal complex. A more exact plan of Rancho de las Cabras was drawn, and professional surveyors from the Texas Parks and Wildi ife Department made a contour map of the site. Recommendations for future historical and archaeological research are included in this report. 
The Zacatecan Period--Ignacio Calvillo and the Origin of the Calvillo Ranch ................. 30 María Calvillo and the Calvillo Ranch ............. 33 STRUCTURAL HISTORY OF RANCHO DE LAS CABRAS . . . . . . . . . . . . . . . 34 The Queretaran Period, 1755-1772 ............. . 34 The Zacatecan Period, $1772-1794$.............. 35

The Northwestern Corner . . . . . . . . . . . . . . . 37

The Limekiln . . . . . . . . . . . . . . . . . . . . 38

The Trash Pits .................... . 39

Other Associated Construction . . . . . . . . . . . . . 39

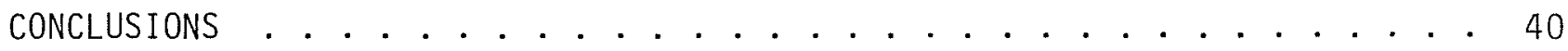

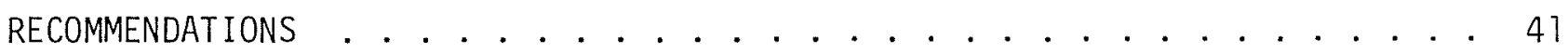

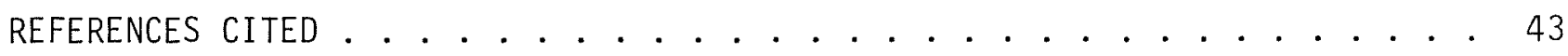
APPENDIX: LITHIC ARTIFACT ANALYSIS FOR THE 1980 AND 1981 SEASONS

AT RANCHO DE LAS CABRAS (Joseph H. Labadie) . . . . . . . . . . . . 47 


\section{LIST OF FIGURES}

1. Plan of Rancho de Tas Cabras, Second Season . . . . . . . . . . 4

2. Plan of Area A . . . . . . . . . . . . . . . . . . . 13

3. Selected Ceramic Sherds . . . . . . . . . . . . . . . . . . . . 17

4. Metal Artifacts........................ . . 21

5. Metal Artifacts... . . . . . . . . . . . . . . . . 22

6. Primary and Secondary Flakes . . . . . . . . . . . . . . . . . 49

7. Flakes ....................... . . . 50

8. Flakes and Chips ...................... . . 53

9. Secondary and Tertiary Flakes and a Chip . . . . . . . . . . . . . . 54

10. Bifaces and Tertiary Flakes . . . . . . . . . . . . . . . . 56

11. Guerrero Points: Thin Bifaces, Group III . . . . . . . . . . . . 62

12. Gunflints............................ 64

\section{LIST OF TABLES}

1. Provenience of Artifacts from Second Season . . . . . . . . . . . 18

2. Provenience of Lithic Artifacts from the 1980 and the 1981 Seasons. . 66 


\section{ACKNOWLEDGMENTS}

Field work for the second season at Rancho de las Cabras was conducted by both ful1-time and volunteer crew members. The full-time crew consisted of James Ivey, Field Director; Lois Flynn, Assistant Director; Katherine Gonzalez, Field Recorder; Stephen Black, Margaret Mehrtens, Elaine Brown, Gregory Sundborg, and Dixie Watkins. Volunteers at the site were Cecil Peel and Margaret Greco. Lab work was done by Sylvia Bento, Katherine Gonzalez, and Elaine Brown. Valuable advice and assistance was supplied by Anne A. Fox. Typing of portions of the manuscript was done by Elaine Brown. Ann Young typed the final version of the manuscript, and Sharon Quirk was the editor.

The principal investigator for this project was CAR Director Dr. Thomas R. Hester, and the co-principal investigator was CAR Associate Director, Jack D. Eaton. 



\section{INTRODUCTION}

This report documents the second season of archival research and archaeological investigations at Rancho de las Cabras, the ranch buildings associated with Mission San Francisco de Ta Espada of San Antonio, Texas, by the Center for Archaeological Research, The University of Texas at San Antonio (CAR-UTSA). Rancho de las Cabras is located on the west bank of the San Antonio River, about four kilometers southwest of Floresville in Wilson County, Texas, and about 37.5 kilometers south-southeast of Mission Espada. Contract number IAC(80-81)2066 for this season's work, issued by the Texas Parks and Wildi ife Department, was signed July 8, 1981, and 22 days of field work began on Thursday, July 16, 1981. Rancho de las Cabras (41 WN 30) is 1isted on the National Register of Historic Places and is a State Archeological Landmark. The investigations were carried out under Texas Antiquities Committee Permit No. 281 .

The vegetation in this area consists of live oak, post oak, and pecan. Mesquite and a variety of thorny underbrush, as well as sparse, short grasses, are the dominant species in the immediate area of the site. The soil of the area varies from tan to medium reddish brown sandy loam that overlies a yellowish brown clayey soil.

Presented in this report is a history of the background of Rancho de las Cabras, its relationship to other mission ranches, and its status in 1772 . The history of the Calvillo family, who acquired ownership of Rancho de las Cabras in 1832, is also reviewed, with the emphasis placed on how this family interacted with and affected the history of the Rancho. The areas of historical research to be accomplished in subsequent reports are:

1. An intensive search for more information on the history of Rancho de las Cabras between 1772 and 1800 .

2. Documentation of the use of the chapel by the local population after secularization of Mission Espada.

3. A study of the relationship of Rancho de las Cabras to the growth of the Floresville arèa.

4. More information on the Calvillo family in the years from 1800 to 1832 , and on the other family-owned ranches of the area.

5. A history of the ownership of Rancho de las Cabras from its acquisition by the Calvillo family to the present.

Included in the Artifact Analysis section is a tabulation of the artifacts by unit, stratum, and artifact type. An intensive study of the lithic artifacts from the two seasons of field work (1980 and 1981) was conducted by Joseph $\mathrm{H}$. Labadie (included as an Appendix to this report), for the purpose of comparing the collection from this site with materials from regional nonhistoric sites. A similar study of the locally made ceramics (generally called Goliad ware if recovered from historic sites) found in large quantities in the trash pits, is planned for the future, again for purposes of comparison. 
The massive quantities of bone recovered this year have not been analyzed. The sample is from a small portion of a large trash pit. This material will be stored and assessed with the entire faunal contents of the pits as a single analysis after a complete excavation. This will be more economical and will produce more consistent results than a series of partial analyses.

In the Recommendations section a series of future excavation problems to be addressed is suggested.

\section{SCOPE OF WORK AND METHODOLOGY}

Excavation methodology concentrated on discrete areas for clues to cultural activity, architectural tracings, and stratigraphic sequences.

Area $A$ was established in the area of the jacal wall found during the first season, 1980, in order to locate other walls, activity areas, or other cultural traces within and outside these walls. In this area, numbers were given to each unit of stratification regardless of whether it was a general deposition, fill within a disturbance, or associated with some feature found during the excavation. This was done to avoid complicated letter and/or number coding systems that suffice for testing but become far too complex for any extended excavation of an occupation site. Of those assigned numbers, many units of stratification were not excavated, and so do not appear in the artifact provenience table. These strata consisted of the fill of each of the many postholes located as the jacal structures were excavated. It was decided to leave the original fill until detailed plans for the stabilization or restoration of the site had been completed by the Texas Parks and Wildlife Department.

Units 17, 18, 19,21,22, 23, 24, and 25 were established to 1ook for architectural information. The excavation involved the removal of wall rubble to a depth sufficient to locate and define wall lines within the rubble. The exceptions to this procedure were Units 17, 19, and 23, which were excavated below the level of simple wall rubble into culturally deposited strata combining architectural and stratigraphic investigations.

Units 16 and 20 were excavated for stratigraphic purposes, in search of culturally deposited material to use for cultural analysis and for dating.

Units involving stratigraphic excavation were screened through 1/4-inch hardware cloth. Artifacts were bagged, and a record was kept of their provenience. Architectural tracing units were shoveled out, and artifacts seen in the process were kept but no attempt was made to screen this material, since the artifact association was by chance rather than by cultural activity. The strata of the area excavation were passed through a 1/4-inch screen, and detailed plans were made of the various structural remains and cultural features found.

Artifacts from all units were bagged according to provenience, and after washing were labeled with a code indicating this provenience. Bags were given consecutive numbers for bookkeeping purposes and to insure that all bags were 
accounted for. Logs were kept of photographs taken, bags filled, and units and strata excavated. A running daily journal was kept. All artifacts are curated at the laboratory of the CAR.

\section{EXCAVATIONS}

The Northeast Corner

Four units were excavated in various parts of the northeastern corner of the compound. Units 18 and 21 were architectural; Units 17 and 23 were both architectural and stratigraphic. Unit 21 was excavated with the intention of locating the front wall of the church; Units 17 and 18 were excavated to check for the presence of an earlier compound wa 11; and Unit 23 was excavated to locate the position of the northeastern end of the north wall (Fig. 1).

Unit $17(1 \mathrm{~m} \times 5.25 \mathrm{~m})$

Stratigraphy

The stratigraphy of Unit 17 followed the general pattern noted in Units 7,8 , and 10 of the first season (Ivey and Fox 1981:19-20, 22-23). The highest, Stratum 1, consisted of about $10 \mathrm{~cm}$ of tan, sandy clay and scattered rubble. This overlaid two strata of very loose dust and sand mixed with chunks of manure. The upper, Stratum 2, was 10-12 cm thick and had only small manure chunks; while the lower, Stratum 3, had large masses of this material.

Underlying these two strata was Stratum 5, a two to four centimeters thick layer of a brown sand with some manure dust resting on a hard-packed pale gray living surface, the top of Stratum 6 . An irregular area of burned material (Stratum 4) was found just above the surface of Stratum 6, generally in the south half of the eastern two meters of the unit. About one centimeter of Stratum 5 underlaid this burned material. The material may be burned manure; it consisted of a layer of black, carbonized fine-grained organic substance topped by Targe patches of white and gray ash.

Stratum 6, six to eight centimeters thick, had lime mixed with clay and some charcoal and bone fragments pressed into the material.

A rough trench ca. $18-20 \mathrm{~cm}$ wide and six centimeters deep was found cut into the hard clay surface of Stratum 6. It apparently originated from the top surface of the burned material in Stratum 4 . The use of this trench was not apparent.

In the west end of Unit 17 a high concentration of sandstone chips and chunks was visible on the surface of Stratum 6 , in a zone about $80 \mathrm{~cm}$ wide with the west edge about $20 \mathrm{~cm}$ from the west end wal1. A $1.5 \mathrm{~m} \times 1 \mathrm{~m}$ section of Unit 17 was extended through the hard-packed surface of Stratum 6 to examine this zone in depth. Beneath the six to eight centimeters of Stratum 6 on the east side of the zone of sandstone chips, a hard, red brown clay surface with few artifacts was found (Stratum 9). Beneath the sandstone chip zone was Stratum 7, a trench about $70-\mathrm{cm}$ wide containing an adobelike material. Stratum 8 


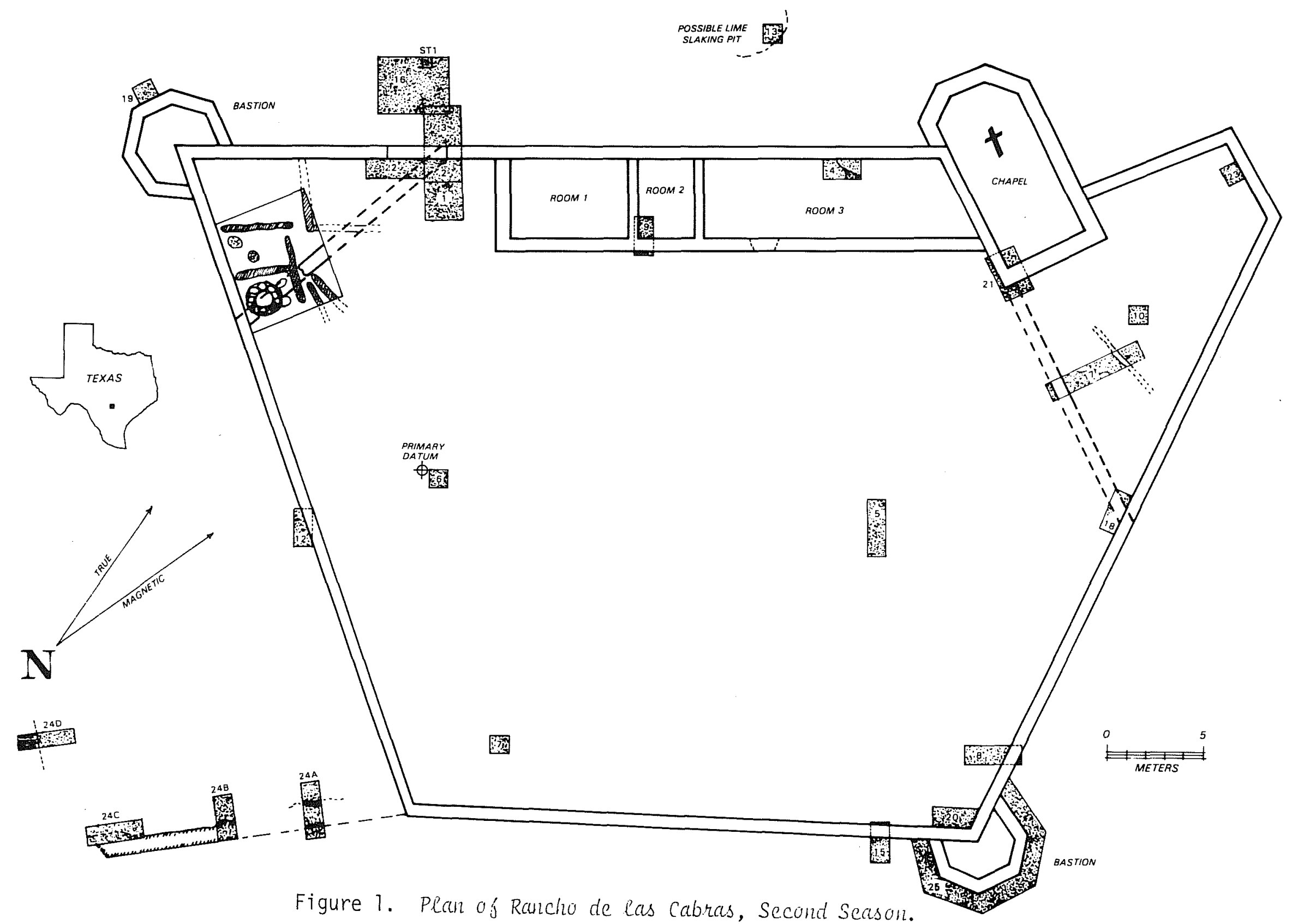


contained increasingly large chunks of sandstone and loose brown sandy dirt. Massive sandstone rocks were found closely set in the north end of this trench, beginning at a depth of about $6-10 \mathrm{~cm}$ below the top of Stratum 9 . These large stones were missing in the south portion of the trench at this depth, but stone may still be in place deeper in the trench.

It was noted that the surface of Stratum 9, east of this stone-filled trench, was relatively sterile. West of the trench, was Stratum 10, a hard-packed dark brown clay with charcoal and bone fragments visible in the surface.

\section{Observations}

The stone-filled trench in the west end of this unit was the remains of the original compound wall in this area. The trench was ca. $75 \mathrm{~cm}$ in width (Fig. 1). Stratum 10 was the last occupational surface within this original wall, and Stratum 9 was the original outside ground surface. The wall was torn down, leaving part of the foundation in the ground, and all but small sandstone debris was moved elsewhere. Over this foundation a hard-packed clay surface had built-up, either through intentional spreading of clay or as a natural result of the usage in this area. The clay looks harder and lighter in color than the local dark red brown sandy earth and possibly could have been an intentionally made and spread adobelike material. On top of this hard, gray clay was a fine, sandy tan brown clay and some manure dust. Some patches of burning had occurred during this deposition, and later a narrow, shallow ditch was dug from the direction of the front door of the church toward the west wall of the compound through a burned area, perhaps as a drainage ditch.

After this shallow ditch was cut, two thick layers of manure built-up along most of the south and east portion of the compound, thus, representing use of the compound as a corral or cattle pen.

The hard-packed, adobelike surface, Stratum 6 , had been seen in Units 8 and 10 from the first season (Ivey and Fox 1981:20, 24), and in Units 20, 21, and 23 discussed below, but not in any units in the northwest compound area. Units 6 and 7 of last season (Ivey and Fox 1981:18, 19) contained a hard, gray brown surface that resembled the surface seen in these eastern units to some extent, but it was not identical.

Unit $18(1 \mathrm{~m} \times 2 \mathrm{~m})$

Unit 18 was an architectural tracing unit placed against the inner face of the west compound wa11, at the point where the original compound wall should intersect it (Fig. 1). It was not excavated below the bottom of the recent rubble stratum which forms Stratum 1 in most units at this end of the compound.

\section{Observations}

Once the brush and rubble were cleared, the original west corner was found with a stub of the compound wall still in place and a clear butt joint where 
the later compound wall began at this corner. The original wall was $66 \mathrm{~cm}$ in width and aligned with the standing west wall of the chapel and the wall foundation in Unit 17. There appeared to be some difference in the size and color of stones selected for the construction of the new add-on wall, also $66 \mathrm{~cm}$ in width, but not enough wall face was cleared to test this sufficiently.

Unit $20(1 \mathrm{~m} \times 2 \mathrm{~m})$

\section{Stratigraphy}

Stratum 1, 15-18 cm thick, consisted largely of a gray tan, adobelike clay, which contained a large quantity of wall rubble, some of it massive. Beneath Stratum 1 was a softer gray tan sandy soil, and the fallen wall rubble continued through the two zones with no layering.

Stratum 2 was the usual layer of light brown, loosely bedded chunks of manure, 10-15 cm thick. Beneath it was Stratum 3, a more compact manure layer about $15 \mathrm{~cm}$ thick.

Stratum 4 was a silty, tan loam, two to three centimeters thick and we11packed onto a hard, white tan-puddled adobe floor or occupation surface. Stratum 4 had a quantity of charcoal flecks that stained it a darker brown in places.

The adobe occupation surface was somewhat uneven with embedded chunks of charcoal and patches of gray ash. No indication of heat reddening was seen on this surface, indicating that the charcoal and ash originated elsewhere and was apparently blown or swept onto the surface.

Fracturing of the puddled clay revealed that it was composed of more than one distinct layer--the top layer flaked off from a lower, well-defined surface containing patches of ash, embedded charcoal fragments, fragments of bone, and mussel shel1. No ceramics were seen on or in the occupation surfaces. The excavation did not penetrate this surface.

Observations

The wall in this corner of the compound showed no sign of a break or filled doorway. Access into the bastion immediately outside the wall at this point was not, therefore, through a door or any other opening at ground level.

\section{Unit $21(2.5 \mathrm{~m} \times 1.5 \mathrm{~m} ; 1 \mathrm{~m} \times 70 \mathrm{~cm}$ extension to the east)}

This unit was excavated as an architectural tracing to look for the facade of the chapel at the approximate point of its southwestern corner. Rubble was found down to and lying on the hard-packed surface at the facade with manure deposits intermixed. The hard-packed surface showed a clear trace of the original compound wall foundation through the hard-packed clay. The facade wall of the church was found still standing to a height of 20-30 cm above this hard-packed surface. Unit 21 was extended one meter to the east along this facade at the level of the hard-packed surface. This excavation revealed that a treasure 
hunter's pit had been dug in the presumed area of the front door. No trace of the doorway was seen in this limited test, although a complete removal of rubble in this area might reveal evidence of a doorway at the foundation level. The portion of Unit 21 inside the chapel revealed that the facade wall was $85 \mathrm{~cm}$ thick and had been plastered on the interior, although only small fragments of the base coat survived in crevices. A treasure-hunter's pit had apparently been dug into the southwestern corner of the chapel, since only loose rubble was found to at least a depth of ca. $30 \mathrm{~cm}$ below the hard-packed surface outside the facade. The wa11s were undercut by 5-10 cm by the treasure-hunter's pit at this depth.

\section{Observations}

The original compound wa11, the west wall of the church, was $66 \mathrm{~cm}$ thick. Apparently the portion that was not incorporated into the chapel was torn down to ground level at the time the chapel was begun. The facade wa11, $85 \mathrm{~cm}$ thick, was then tied to the remaining portion of the original wall at right angles.

The presence of rubble directly on the last occupation surface against the facade of the chapel, before the beginning of the buildup of a manure deposit in the courtyard, argues that the church had been abandoned long enough for collapse to begin before the compound became a corral. A similar sequence is seen in Unit 20 in the southeast corner of the compound, where large stone blocks were also found lying on the last occupation surface, before the manure buildup began.

Unit $23(1 \mathrm{~m} \times 1 \mathrm{~m})$

This unit was placed on the inside face of the northeastern corner wall to examine the stratigraphy and to determine the thickness of the wall after the majority of the wall line had been traced on the ground by clearing loose dirt and rubble (Fig. 1).

\section{Stratigraphy}

Stratum 1 was $4-10 \mathrm{~cm}$ of loose gray tan, sandy soil sloping down toward the northeast across the top of the surviving wall stub. Stratum 2 was a layer of yellow sandy clay, sandstone chips, and chunks, four to six centimeters deep, and lensing out toward the west away from the wall. Stratum 3 was gray tan, sandy soil in a layer 22-26 cm thick. Stratum 4, 14-16 cm thick, was a single, we11-packed layer of manure chunks. Stratum 5 was a fairly solid gray sandy clay with a high percentage of ash stain and some charcoal. This rested on Stratum 6, a hard-packed, pale gray adobelike surface similar to that in Units $8,10,17,20$, and 21 .

\section{Observations}

The $49 \mathrm{~cm}$ of wall height surviving in this northeastern corner is surprising, considering the almost complete lack of any traces of ruin on the surface in 
the area. The hard-packed surface is about $85 \mathrm{~cm}$ lower than at the line of the old compound wall foundation in Unit 17, a distance of about $14 \mathrm{~m}$ (a drop of six centimeters per meter), and $1.45 \mathrm{~m}$ below the occupation surface in the northwestern corner of the original compound. This slope channeled rainwater and surface wash into this area, which produced deep deposits of dirt and manure.

\section{Bastions}

On the northwest and southeast corner of the compound were circular mounds of rubble, indicated by local tradition to be the ruins of bastions, or defensive positions designed to allow lines of fire along the outside wall faces of the compound. Dirt and loose rubble were removed from the edges of these mounds until the tops of the wall remains were clearly defined. Construction of the bastions was found to be less fine and of larger chunks of stone than the perimeter compound walls. No distinct difference in the color of the stone selected was seen, but no formal study was made of this.

Unit $19(1 \mathrm{~m} \times 1 \mathrm{~m})$

This unit was placed against one face of the northeastern bastion to determine the level of the surface at the time the bastion was constructed.

\section{Stratigraphy}

Stratum 1 was a mass of dirt and rubble sloping down from the top of the surviving wall bases. The wall in this area stands to a height of about $60 \mathrm{~cm}$ above the surface of construction.

Strata 2 and 3 were hard-packed, red brown, sandy clay layers with some bone fragments and a few unglazed ceramic fragments. Each stratum was $\mathrm{ca} .10 \mathrm{~cm}$ thick, but there was little difference between the two, and there is some indication that they could have been subdivided into many smaller strata.

Stratum 4 was a hard-packed, sterile, red brown, sandy clay with a small quantity of bone and pottery fragments pressed into its top surface.

\section{Observations}

Very little cultural material buildup was apparent outside the northwestern bastion. The deposition resembled that seen outside the main compound walls in Units 12 and 15, excavated in 1980 (Ivey and Fox 1981:27, 28, 30). The northwest corner of the compound still existed within the bastion structure. The bastion walls are $66 \mathrm{~cm}$ thick, as were all the perimeter compound walls.

\section{Unit 25}

This unit began as a small area of rubble removal on the southeastern corner to determine if a wall survived in the area of this bastion as it did at the 
northwestern corner. Once a wall edge was identified, rubble was cleared to follow this wall around the circumference of the bastion. No further excavation was done, nor were the stratified deposits below the rubble disturbed.

\section{Observations}

The original corner of the compound survived within this bastion to a greater height than the bastion walls themselves. The fill within the walls of both bastions was a pale brown sandy soil with white caliche specks. This soil also made up most of the earth fill between the loose wall rubble around both bastions. It would appear that both bastions were filled with earth between their perimeter walls and the corner of the original compound, up to some height above the contemporary ground level. Access to the bastions was not through a ground level doorway, and therefore must have been by stairs or a ladder to a higher than ground level platform.

\section{Southwestern Corner}

Traces that appeared to be a wall were seen extending westward from the southwestern angle of the compound. A series of squares were laid out across these traces in an attempt to define any structural details. These were Units 24A, 24B, 24C, and 24D. A11 were one meter by three meters and were excavated only to the base of the rubble zone.

This limited testing revealed that a distinct wa11-1ike structure existed here, but it appeared to have had a very shallow foundation, if any. The south face of this wa11-like structure seems to have been fairly straight and regular, but the north face appears much more irregular and i11-defined. The apparent width varied between $85 \mathrm{~cm}$ (one vara) and $145 \mathrm{~cm}$ (1.7 varas). The stones seem to be resting directly on the last occupation surface in this area, rather than set into a footing trench.

The west end of this wal1-like structure was not clearly defined. It seemed to simply fade out, the rocks growing smaller and more scattered in the last meter excavated. The east end butted against the southwestern corner of the compound, with its south face matching the south face of the compound wall (Fig. 1).

Unit 24D was excavated north of the west end of the wall-1ike structure, along a distinct ridge or rise extending from the end of the "wal1" in a curve to the northwestern bastion. This unit located no wall traces, but found a hard, white adobelike pavement sloping up the face of this rise towards the east under three to five centimeters of loose tan, sandy clay. This pavement thinned out as it sloped up.

\section{Observations}

The true nature of this wall-like structure was not revealed by these tests. Whether these traces are structural or perhaps only a retaining wall or terracing wall arrangement cannot be determined from such a limited examination. 
The Northwestern Gateway

Units 2 and 3, excavated in 1980 (Ivey and Fox 1981:12, 14-15), found what appeared to be a gateway opening blocked with a rough plug of stones. Unit 22 was one meter by three meters and extended westward along the south face of the north wall from the west edge of Unit 2. This unit was an architectural tracing unit and only removed rubble and earth from the above-ground wall remains.

\section{Observations}

The extremely rough, irregular stonework seen in Unit 2 was followed across $1.87 \mathrm{~cm}$ of Unit 22. At this point a fairly clear transition to good stonework occurs. The length of very poor stonework was about $2.5 \mathrm{~m}$, an acceptable width for a gateway.

The presence of a gateway in this area and its relationship to the history of the remainder of the site was further complicated by the finding of a second early compound wall in Area A nearby, a wall which intersected the north wall at the point where this gateway feature began in Unit 2. This will be discussed in the section detailing the excavation of Area A, page 12.

Trash Pits

Shovel Test 1, $\left(50 \mathrm{~cm}^{2}\right)$, excavated during 1980 (Ivey and Fox 1981:7) found what appeared to be the edge of a trash pit outside of the northwestern gateway area. The goal this season was to completely excavate this possible trash pit. Unit 16 , originally $1.55 \times 2.50 \mathrm{~m}$ was laid out so that Shovel Test 2 was centered on the north edge.

When the stratum of origin of the trash pit was reached, it was found that there was not one, but at least four and probably more trash pits of various sizes overlapping each other. Unit 16 was expanded in an attempt to reach the edge of this complex, but it quickly became apparent that there was far too much volume to permit a complete excavation this season. In addition, the lower strata of the largest pit were full of articulated bone, apparently butchering debris similar to that found in the San Antonio River-Alamo Linkage excavations. Since such a deposit would be a valuable comparative collection, similar in date and cattle population to those in the San Antonio River-Alamo Linkage project, it was decided that excavation of these strata should wait until an appropriate set of cameras, camera platforms, cleaning equipment, personnel, and sufficient time have all been assembled.

\section{Stratigraphy}

Stratum $1(1.55 \mathrm{~m} \times 2.50 \mathrm{~m}$, extended to $3.75 \mathrm{~m} \times 3.00 \mathrm{~m})$ was a moderately, hardpacked, red brown, sandy clay, 6-10 cm thick, with some small fragments of bone, charcoal, ceramics, and sandstone. Massive stone chunks of sandstone rubble, some $50-60 \mathrm{~cm}$ across, were visible on the present surface in the southwestern corner. 
Stratum 2 was a very hard-packed, red brown, sandy clay, $10-12 \mathrm{~cm}$ thick, with fragments of mortar or adobe. A portion of a small trash pit full of ashes, charcoal, bone fragments, and some ceramics was transected in the southwestern corner (Strata 7 and 8). At the base of Stratum 2 a layer of large sandstone rocks was encountered along the south edge of the unit. These appeared to have been intentionally laid down rather than to have fallen off the wall. The area uncovered was too small to allow a hypothesis of the intended use for these rocks, if any. Smaller cobbles were scattered over the rest of the unit between Stratum 2 and Stratum 3.

Stratum 3 was a loose deposit of tan to red brown sandy clay with a considerable variation in its appearance horizontally and vertically. The impression was of multiple lenses of deposition and disturbance, but the dusty nature of the soil obscured details and made the difference difficult to see. Stratum 3 within the original outline of Unit 16 was removed as a layer $30 \mathrm{~cm}$ thick, tapering to six centimeters at the east side of Unit 16. Stratum 3 overlaid a sloping ashy surface that dipped down into the trash pit, which was found in Shovel Test 1. When the $3 \mathrm{~m} \times 3.75 \mathrm{~m}$ extension of Unit 16 was excavated, it was found that Stratum 3 was actually two strata, divided as Stratum $3 a$ and $3 \mathrm{~b}$. Stratum 3a was 8-12 cm in thickness, mixed, and disturbed. The Strata 3a/3b interface showed the outlines of three overlapping trash pits and possible evidence of two others. This interface appears to have been the contemporary ground surface of most of these trash pits. Stratum 3b was the top stratum of the largest trash pit in the area, through which most of the other trash pits were excavated. The later trash pits formed a complex mass on the west side of the extended unit, and one (Stratum 5) was bisected within the original outline of Unit 16.

Stratum 4 was a multiple-lensed deposit of charcoal, ash, bone, and ceramics about $16 \mathrm{~cm}$ thick, sloping down into the large trash pit. It overlaid Stratum 6 , which was a dark brown, gritty layer full of articulated skeletal segments of butchered cow and other animals, charcoal, ash, and artifacts. Only nine centimeters of this stratum was excavated in the southwest area of the unextended Unit 16 before it became obvious that the bone deposit was far too concentrated, complex, and important to be removed in the time available, and the excavation of the unit was stopped.

\section{Observations}

The earliest cultural activities in this area are associated with trash disposal. A series of overlapping pits were dug by the occupants of Rancho de las Cabras and filled with trash at varying rates, indicating the $7 \mathrm{ikel}$ ihood of a gate or door nearby.

The earliest pit fill was Stratum 6, which apparently dates from ca. 1755-1760 according to the artifacts (i.e., a large amount of butchering discards and random trash). Stratum 4 appears to be multiple layers of trash from hearth cleaning (i.e., lenses of ash, charcoal, bone, and trash). Stratum 3b may be a slow accumulation of dirt and garbage with no clear lens structure in the fill, while Stratum $3 a$ is probably largely a series of backdirt lenses from the excavation of new trash pits near the west side of the unit. 
The top of Stratum 3a shows what appears to be intentionally placed rocks in the western half of the unit, overlaid by a hard-packed stratum of sandy clay with many very smal1 fragments of bone and ceramics, Stratum 2. This may correspond to the closure of the old gate and the construction of a new corner on the northwest, leaving a new gateway facing onto the old trash dumping area. The intentional stone and clay fill seems to have been a road surfacing fill placed into the old trash pit depressions for leveling.

Stratum 1 was the usual blown-in dirt and collapsed wall rubble seen everywhere on the site.

Area A

This unit was five meters by six meters, and was placed against the inside of the west wall, centered on the foundation trench of the palisado or jacal building seen in Unit 11 excavated in 1980 (Ivey and Fox 1981:24, 26-27). The unit was excavated in order to trace a major portion of the jacal building and its associated activity areas.

Stratigraphy

Unit 11, excavated last season, was emptied of its backfill, and the profiles cleaned. Removal of the strata was begun at the edge of Unit 11 and carried across Area A (Fig. 2).

Stratum 1 was largely fallen wall and rubble piled against the remains of the wa11, lensing out towards the east. Mixed with the stone was sandy tan clay that became more hard packed as the rubble thinned out. The thickness varied from 10-12 cm near the wall to less than two centimeters on the southern and eastern edges of Area $A$.

Stratum 2 is similar in its appearance and thickness. After the removal of Stratum 2, a well-defined linear depression was visible continuing towards the east for a distance of about $2.2 \mathrm{~m}$ from the east end of the section of the jacal trench found in Unit 11. At ca. $2.2 \mathrm{~m}$ this linear depression turned a right angle to the north and continued another $2.4 \mathrm{~m}$ before becoming undefinable. No other linear depression features were seen at this level.

A concentration of rubble south of Unit 11 next to the wal1 appeared to be wal1 fal1 mixed with some other feature, which was about three meters east to west and two meters north to south in size. The outline of the feature was not clear at this level.

Stratum 3 was a series of intermixed lenses of ash and charcoal with large quantities of bone near the wal1. These lenses blend into a series of multiple lenses of pale, lime-stained red sandy clay and darker red sandy clay with little lime. As these lenses of burned clay, lime, and ash were removed, a series of jacal wall trenches with post molds inset became visible. The surface was cleaned to the top of Stratum 4, which appeared to be an occupation surface of hard-packed tan to brown clay. At this point a number of structural 


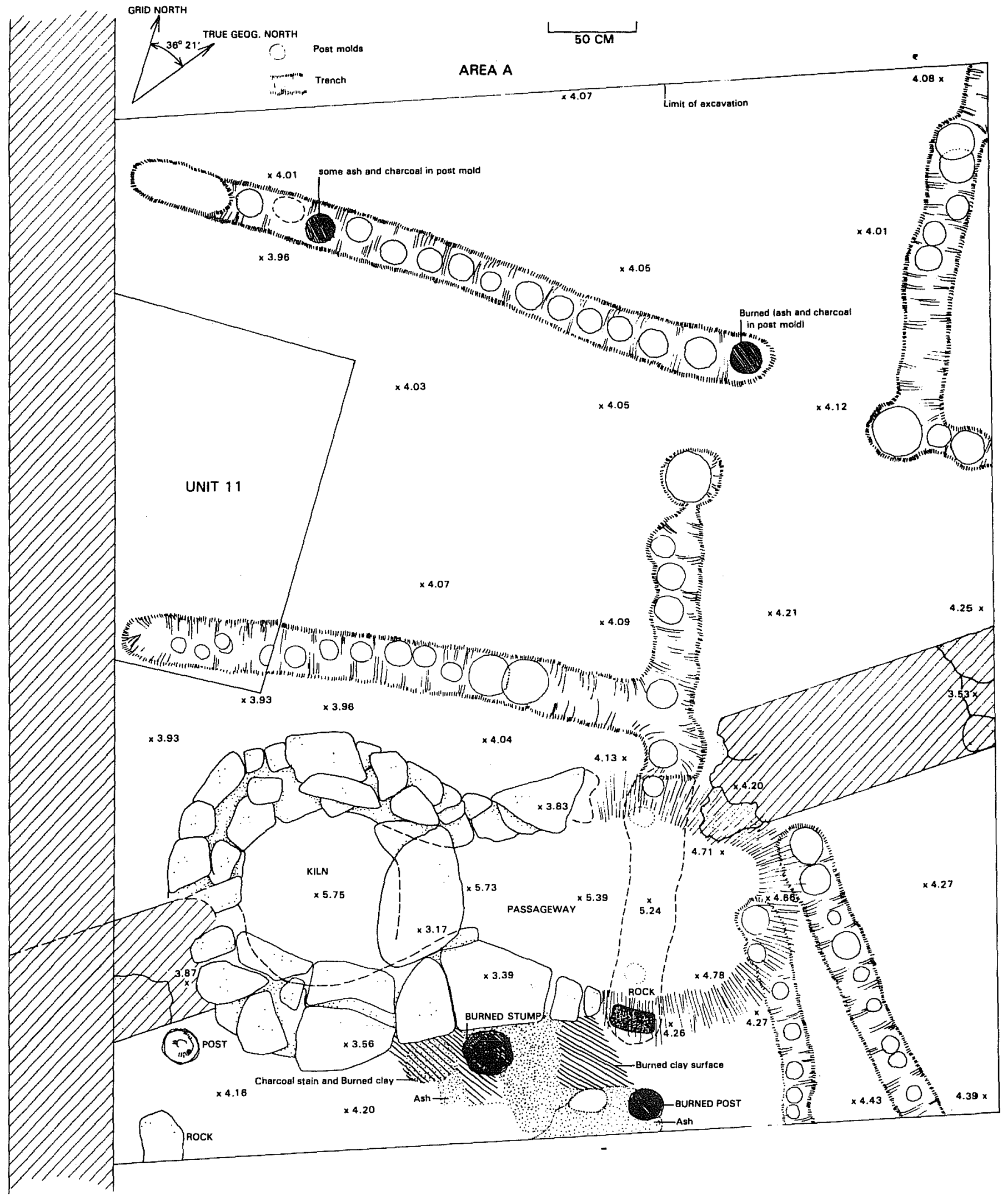

Figure 2. Plan of Area A. 
features were clearly defined. In the southwestern corner of the area, the stone rubble was found to be from a circular structure about $1.6 \mathrm{~m}$ in diameter. This circular structure had a cylindrical central well about $90 \mathrm{~cm}$ in diameter, full of ash, lime, charcoal, bone, ceramic fragments, stone rubble, dirt, and burned clay. Just east of the well was a circular depression about $1.6 \mathrm{~m}$ in diameter filled with a soft gray brown sandy clay with the appearance of a filled pit. North of these two features, two well-defined, jacal-walled room outlines were found. Each was delineated by a ditch containing a series of post molds varying in diameter from $15-25 \mathrm{~cm}$ and usually either in contact with other post molds or with gaps between of less than five centimeters. Clear ridging of the hard-packed adobe or clay floor surfaces indicated that the mud of the floor had continued up the face of the walls. The first room to the north (Jacal Room 2) had two openings at the two eastern corners. The southeastern opening was $45 \mathrm{~cm}$ wide; the northeastern opening was $\mathrm{ca} .40 \mathrm{~cm}$ wide. Jacal Room 3, north of the first room, had an opening in the walls $65 \mathrm{~cm}$ wide at its southeastern corner and an apparent second opening in the center of its south wal1 $20 \mathrm{~cm}$ wide. Two hearths with a fine gravel fill were found in Jacal Room 2, both of which had previously been seen, in part, in Unit 11 (Ivey and Fox 1981:26). A slight depression just east of the southeastern corner of Jacal Room 3 indicated that there may have been a jacal wall section running east from this corner at an earlier time. In the center of the eastern side of Area $A$ was a mass of solidly embedded stone rubble at the surface of this occupation floor. The color of the surface ranged from pale tan to dark brown, and varied from an adobelike material to a packed brown sandy clay. Numerous small bone fragments and some small ceramic fragments were found embedded in this surface.

Stratum 4 was a lower occupation buildup, apparently the original dwelling deposit in the area; it was two to six centimeters thick and more or less even throughout the area.

After the second occupation floor at the base of Stratum 4 was cleaned, it became clear that the jacal structures had originally been more extensive than they had been at the time of the later buildup of Stratum 3 . The jacal wall forming the east side of Jacal Room 2 continued south, forming the wall of Jacal Room 1. The southeastern doorway into Jacal Room 2 had originally been a closed corner. A third hearth without gravel fill was found in Jacal Room 2. A jacal wall was found extending east from the southeastern corner of Jacal Room 3 , forming Jacal Room 4. Several of the post molds in the walls showed traces of having been burned in place.

The southern half of Area A showed far greater complexity. The circular stone structure was completely cleaned, and the circular depression on its east side was emptied and was found to have been an oval passageway into the circular structure with an opening formed by a stone lintel, a large sandstone boulder. All of the stones of the circular structure showed intense heat reddening, and patches of a heat-reddened, crumbly clay lining were found on the interior surfaces of the structure. The opening into the passageway on the east was ca. $50 \mathrm{~cm}$ wide at its narrowest point and $55 \mathrm{~cm}$ from the bottom of the lintel to the floor of the passageway. A series of hard lenses of mortar or lime filled this opening. Fragments of a copper alloy sheet were found embedded in the surfaces of these lenses. Traces of a jacal wall trench and some post molds 
were visible in the surface of the passageway, where the eastern wall of Jacal Room 1 had been removed to construct the passageway.

The entire circular stone structure and passageway were found to have been built into the foundation of a stone wall, which had originally crossed this area. Inspection of the present west wall of the compound at the intersection of this foundation indicated that the original corner was still present in the stonework; and, that from this corner to the north, the wall was a later addition. Inspection of the eastern end of the alignment of the foundation where it intersected the north wall showed that the eastern end of the north gateway found in the 1980 season of field work had originally been the northeastern corner of this origina] wa11. No traces of a foundation were seen in 1980 , but a disturbed area with rodent holes and vegetation roots probably marked the line of the footing trench itself. The mass of stone seen earlier at the center of the east side of Area $A$ was found to be a slightly higher portion of this footing, showing through the upper occupation surface. The eastern jacal wall trench of Jacal Room 1 was found to have been cut through this foundation prior to the excavation of the oval passageway leading into the circular stone structure.

South of the original stone wall footing, two other jacal wall trenches were found, extending southeast at approximately right angles from this wall and diverging slightly from each other. Nearest the stone wall the jacal wall trenches were $15 \mathrm{~cm}$ apart, while at the point where they extended beyond the limits of Area A the jacal wall trenches were $45 \mathrm{~cm}$ apart. The westernmost of the two trenches stopped about $40 \mathrm{~cm}$ short of the stone wa11, while the other stopped at a distance of about six centimeters from the stone wall.

Bone fragments, small pieces of ceramics, charcoal, and ash were embedded in the occupation surface, which was similar in color and material to that seen at the top of Stratum 4 .

\section{Observations}

The original wall of the compound in Area $A$ had cornered about $1.4 \mathrm{~m}$ north of the south edge of Area $A$ and extended northeast out of the unit. Some jacal structures had stood within the original wa11. Al1 of the jacal structures and occupation surfaces, which extended outside of or across this wall, were built and lived in after the reconstruction. After a period of occupation in these jacals, a circular stone structure with a passageway entering it on the east was built into the foundation of the original wal1, apparently using the stones removed from the foundation to construct at least part of the structure. The construction necessitated the removal of at least part of a jacal structure in the area. This structure of stone shows extensive heat reddening and is associated with a great deal of ash, charcoal, fire-reddened clay, and lime dust. This evidence suggests that it served as a small lime burning kiln (see the discussion in the Structural History section).

The kiln was apparently in use while some occupation continued in the jacals. Eventually this occupation stopped, but the kiln continued in use for a time, covering the entire northwestern corner with a thick deposit of discarded 
burned lining clay and lime residue. There are some indications that the jacals may have burned. Eventually the kiln went out of use, and its interior was used as a trash pit until it was full. The series of mortar deposits within the kiln may have been the result of 1 ime residue from water left inside to harden into mortar, or there may have been some attempt to close the passageway opening and to use the kiln for some other purpose.

\section{ARTIFACT ANALYSIS}

One of the principle results of the first season of field work at Rancho de las Cabras in 1980 was the determination that the primary occupation of the site occurred between ca. 1760 and ca. 1820. Some later 19th- and 20th-century material was found, but always in a context indicating that the artifacts were the product of "sporadic visits by local hunters, picnickers, and treasure hunters" (Ivey and Fox 1981:30). This chronological pattern continued to be demonstrated during this season's field work: all artifacts indicate that the end of continuous occupation at Rancho de las Cabras on any scale was ca. 1820, and perhaps even earlier.

Artifact proveniences are shown in Table 1. The various classes of artifacts are grouped into use categories in order to define general activity areas in the ranch compound. The categories used are very general, and certainly should not be considered more than an initial sorting of the artifacts. The actual quantity of artifactual material is sma11, and most of the artifacts are very fragmented. Ceramics, for example, were usually so small that only a color classification was made. An intensive study of the entire artifact collection from all seasons of work will be included in the final report on these excavations.

Ceramics were divided into five general classes: (1) unglazed, including handmade, open-fired pottery; (2) lead-glazed ceramics, divided into decorated and undecorated; (3) tin-enameled ceramics, most of which were Mexican-made majolica; (4) porcelain, including several sherds of bowls imported from China during the Colonial period (Fig. 3,a-d); and (5) 19th-century ceramics, divided into earthenwares and stonewares.

The tin-enameled ceramics were further divided into four subclasses:

1. San Elizario (Fig. 3,e), a majolica type with a white background, over which is painted blue decorations with black or dark brown accent marks and lines. This majolica type has a well-defined period of use in Texas, 17551790. For a more complete discussion of the pattern and dating of this majolica type, see I vey and Fox (1983).

2. Blue-on-White, a general color class into which was placed all sherds that had blue decorations on a white background with no other visible colors or accents.

3. Polychrome ceramics (Fig. $3, f-i, k$ ), where all sherds that had colors other than blue or blue with black accents were placed. Included in this class was the majolica type called Monterey (Fig. 3,j), which has decorations in green, 


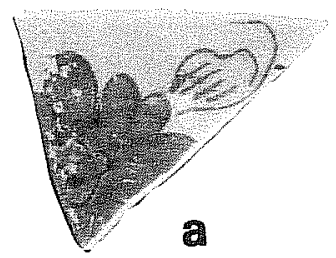

a

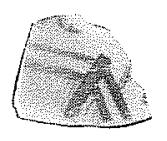

b
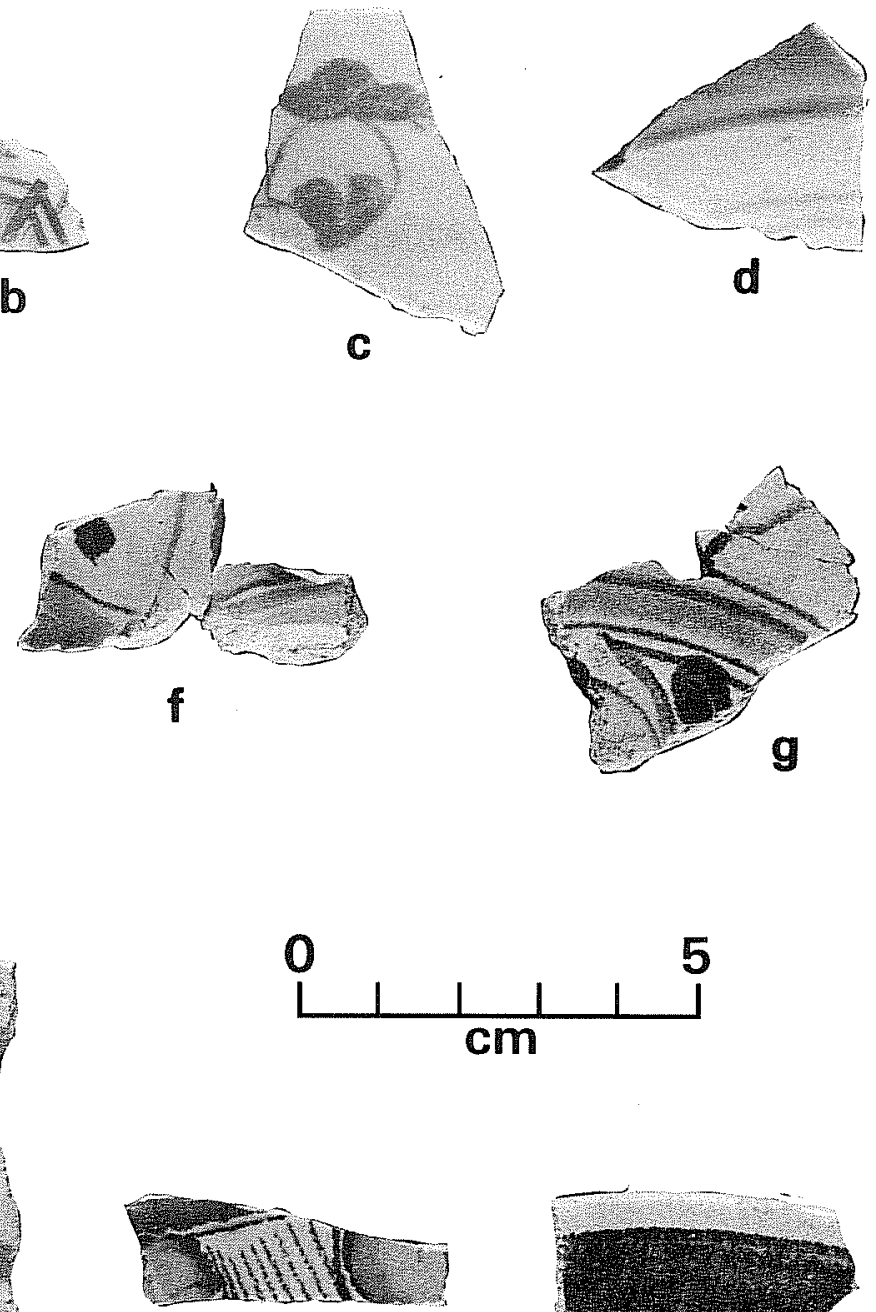

h
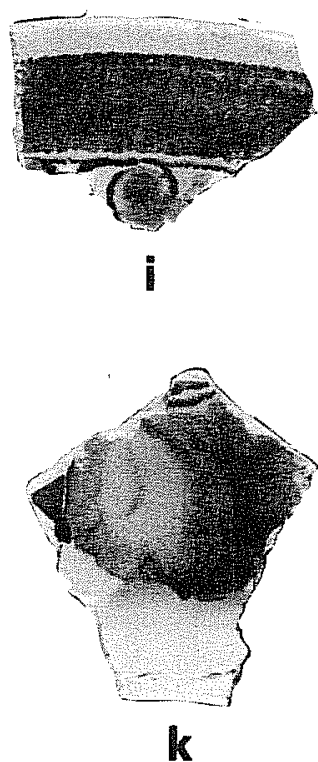

Figure 3. Selected Ceramic Sherds. a-c, oriental porcelain cups or bowls, red painted over glaze; Area A, Stratum 4; Unit 16, Stratum 3; Area A, Stratum 3; d, oriental porcelain plate, blue underglaze, Unit 16, Stratum 4; e, majolica plate, San Elizario, Unit 16, Stratum 1; f-g, k, majolica plate, unidentified polychrome, Area $A$, Stratum $44 ; \mathrm{h}$, majol ica plate, unidentified polychrome, Area A, Stratum 2; $i$, majolica plate, unidentified polychrome, Area A, Stratum 8; j, majolica plate, Monterey polychrome, Unit 17, Stratum 3. 
TABLE 1. PROVENIENCE OF ARTIFACTS FROM SECOND SEASON

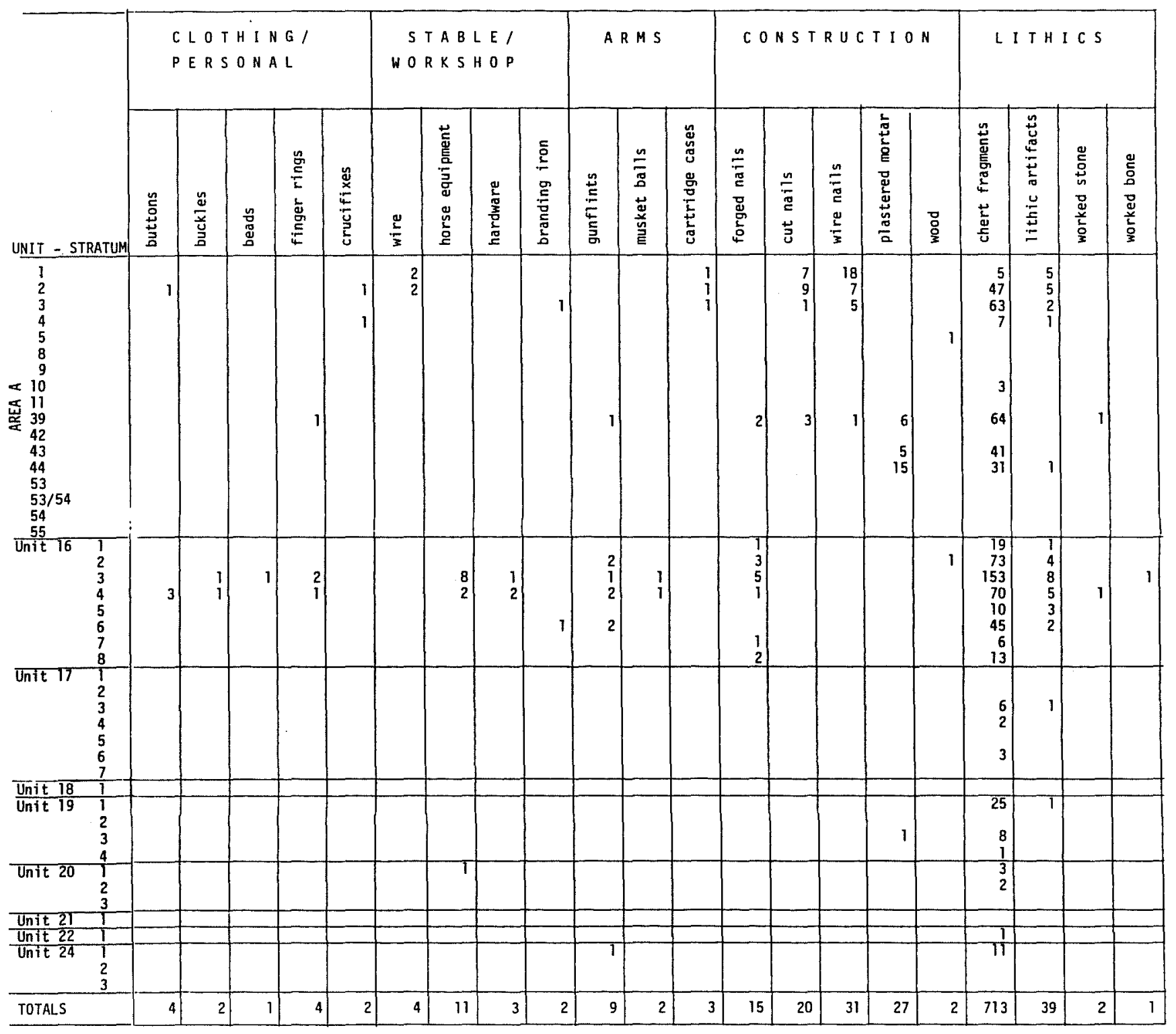


TABLE 1. (continued)

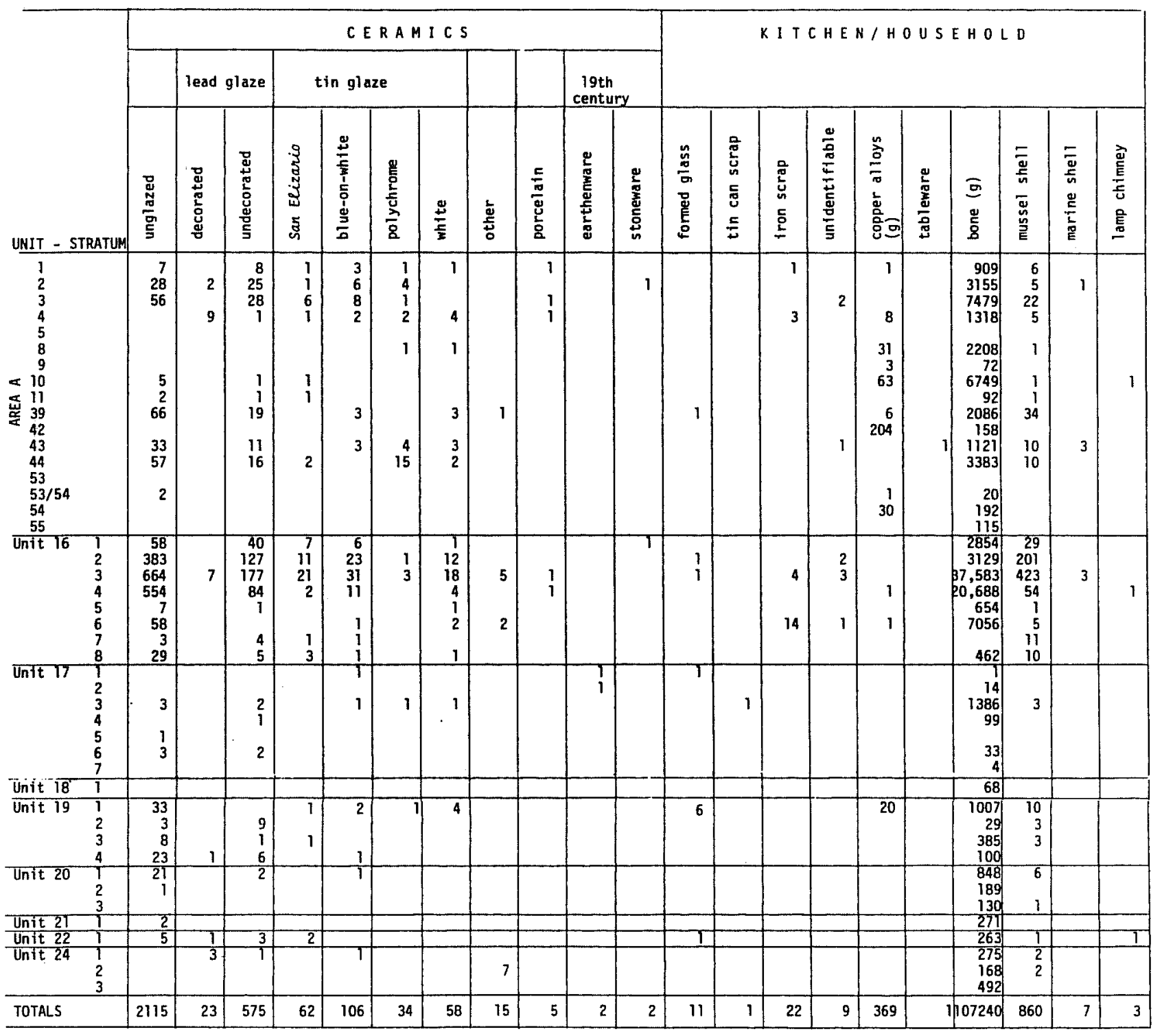


gold, orange, and yellow with brown or black accent marks (for a more complete discussion of this type, see Ivey and Fox 1983).

4. White, where all undecorated tin-enameled sherds were placed. Included in this group was one sherd of faience, a tin-enameled ceramic resembling majolica and usually originating in France.

Artifacts that were put into the Kitchen/Household group were items such as bottle fragments, classified as "formed glass"; fragments of modern tin cans; fragments of scrap iron; various items which may be recognizable, but for which no specific identification has been found; flat copper alloy fragments which probably began as copper or brass pots and pans, listed under "copper alloys"; and tableware or cooking utensils (Fig. 4,a). Also included in this group are the faunal remains which are tabulated by weight for bone and bone fragments and by count for mussel shells and marine shells. An unusual item included in the "unidentifiable" classification was found in Area A, Stratum 43 (Fig. 5,h). The object resembles a pencil. It consists of a piece of graphitelike material held in a metal tube by a knurled collar. The entire assemblage is $3.4 \mathrm{~cm}$ long and $0.7 \mathrm{~cm}$ in diameter, and appears to have been designed to be held in a small handle or "penstaff." The lead shows several use or sharpening facets. There are no specific reasons to suspect that this object is intrusive, so at the present the assumption is that it is indeed a Spanish colonial pencil.

The Clothing and Personal group contains items pertaining to clothing (Fig. $5, e)$, sewing, shoes, buckles, and personal adornment such as jewelry and rings. Two fragments of decorative buckle were found. One buckle fragment, from Unit 16, Stratum 3 (Fig. 5,g), of a cast copper alloy, had intricate decoration combining the sun, moon, and stars with slight traces of an iron crosspiece. The other, from Unit 16, Stratum 4 (Fig. 5,f), was decorated with scrollwork, but the fragment did not include the area of the crosspiece. Among the items of personal adornment were two crucifixes and two finger rings. The crucifixes were of a copper alloy with finely molded scrollwork detail and set stones of glass. One was a solid crucifix, with a small ring on the back of the top arm and six dark blue glass insets, found in Area A, Stratum 4 (Fig. 5,a). Half of a segmented crucifix with round and square aquamarine glass insets was found in Area A, Stratum 2 (Fig. 5,b). Similar crucifixes have been found in the San Antonio River valley missions (see, for example, Schuetz 1969:Figs. 20,J and $21, F)$, and at Michilimacinac in Michigan (Petersen 1964:52). One finger ring from Area A, Stratum 39 (Fig. 5,C), had a molded clear glass central inset, flanked by smaller cobalt-colored, faceted glass insets in a copper alloy ring. This is identical to a variety found at Michilimacinac (Stone 1974: Fig. 57,B). A copper finger ring with cast decorative engraving and a faceted glass inset of indeterminant color was from Unit 16, Stratum 3 (Fig. 5,d).

The Stable/Workshop category includes all fragments of wire, all recognizable items from horse harnesses, saddles, and other horse trappings, such as coscojos, which are the various danglers and jinglers so common as decorative items on Spanish horsefittings (Simmons and Turley 1980:190). Also included are barn and workshop tools and hardware, branding irons and other miscellaneous iron items which are clearly not kitchen or household utensils. 


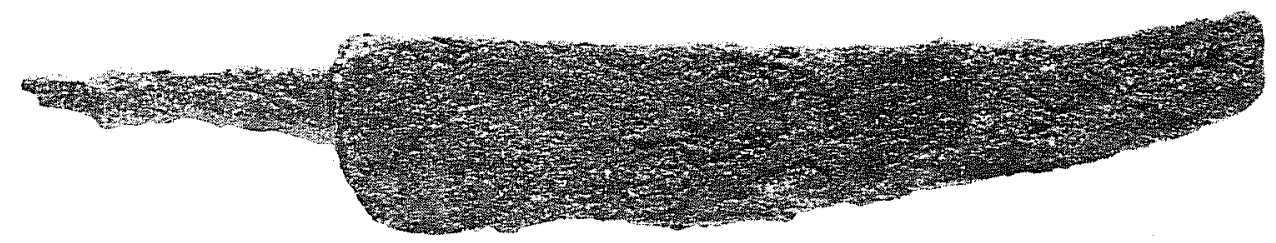

a
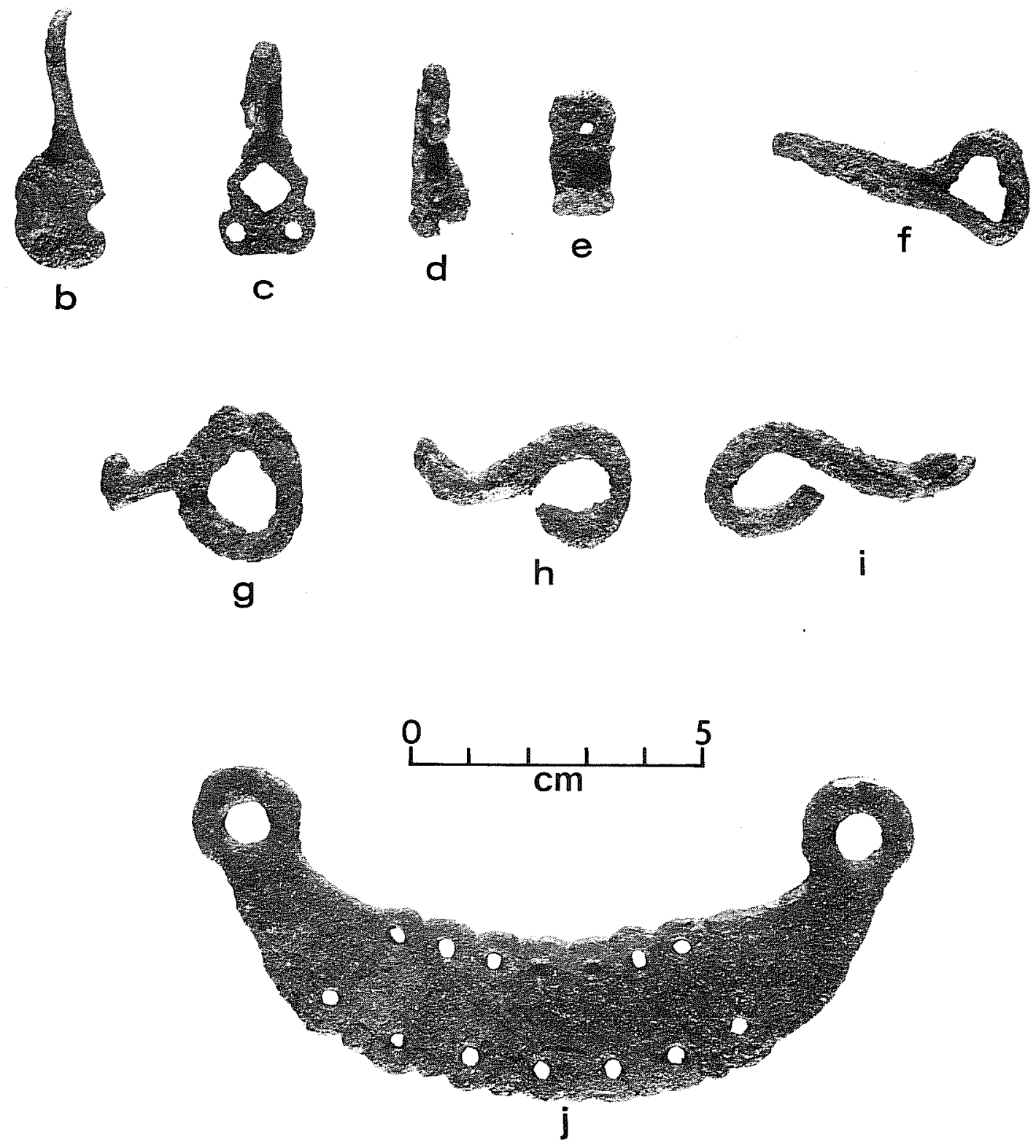

Figure 4. Metal Artifacts. a, knife, Area A, Stratum 43; b-d, jingles (coscojos), Unit 20, Stratum 1; Unit 16, Stratum 3; Unit 16, Stratum 4; e, tab which attached heel chain to spur, Unit 16, Stratum 4; $f$, portion of snipe hinge (gosne), probably from chest of cabinet, Unit 16, Stratum 3; g-i, rein chain (cabestrillo) from bridle bit, Unit 16, Stratum 3; j, bridge (puente) from bridle bit, Unit 16, Stratum 3 . 


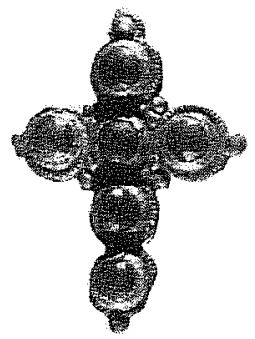

a

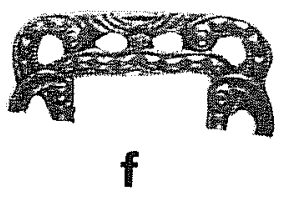

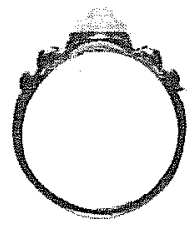

C

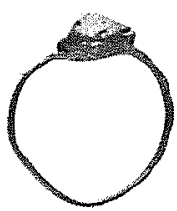

d

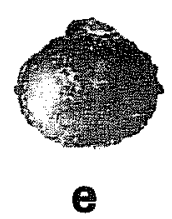

$\mathbf{e}$

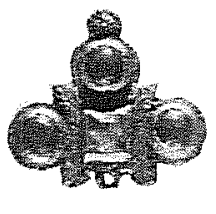

b
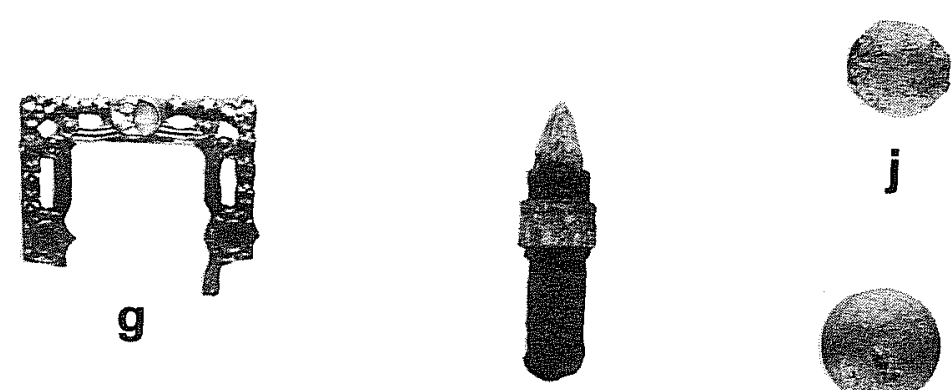

h
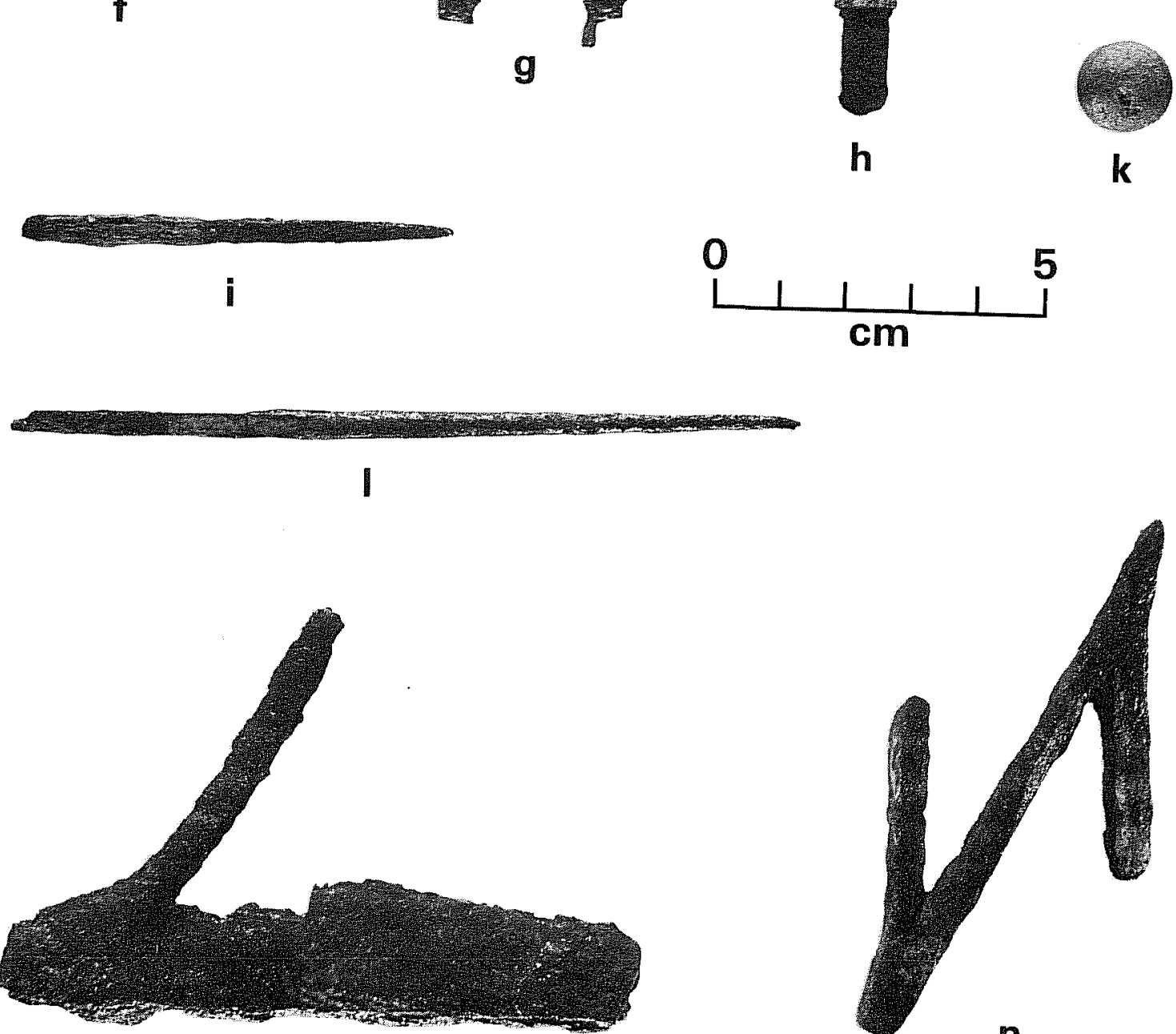

m

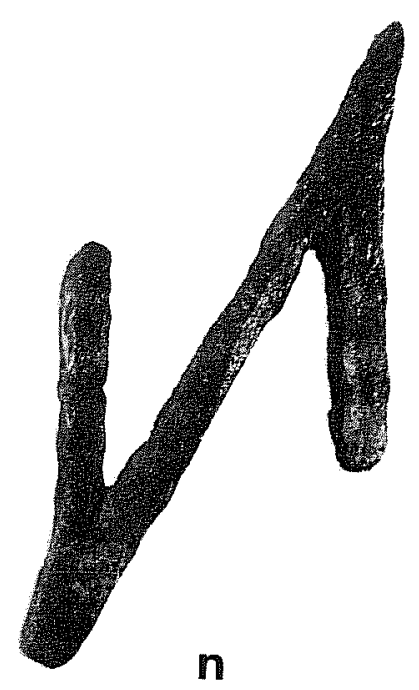

Figure 5. Metal Artifacts. a, crucifix, Area A, Stratum 4; b, crucifix, Area $A$, Stratum 2; $c$, ring, Area $A$, Stratum 39; d, ring, Unit 16, Stratum 3; e, compound button, Unit 16, Stratum 4; $f$, buckle fragment, Unit 16, Stratum 4;

$\mathrm{g}$, buckle fragment, Unit 16, Stratum $3 ; \mathrm{h}$, unidentified object, Area A, Stratum 43 ; $i$, aw1, Unit 16, Stratum 6; $j$, musket ba 11, Unit 16, Stratum 4; k, musket bal1, Unit 16, Stratum 3; 1, awl, Unit 16, Stratum 3; m, branding iron fragment, Unit 16, Stratum 6; $n$, branding iron fragment, Area A, Stratum 3 . 
Two needlelike iron tools, one $13.2 \mathrm{~cm}$ long from Unit 16, Stratum 3 (Fig. 5, 1) and the other $6.6 \mathrm{~cm}$ long, from Unit 16, Stratum 6 (Fig. 5,i), resemble awls found at Michilimacinac (Stone 1974:155-157). One of the specimens (Unit 16, Stratum 6) has traces of wood imprinted in the rusted surface of the metal tool. This is probably the remains of the handle. Both iron tools have a rounded shaft to about the midpoint of the tool, and a rectangular shaft from the midpoint to the far end. The rectangular portion was apparently set into the handle.

A number of parts of horse harness were found in Unit 16 at various levels. Several of these were parts of the bridle bit used to control a horse. These were a puente (Fig. 4,j) or bridge (Unit 16, Stratum 3), several coscojos (Fig. 4,b-d) or jinglers (Unit 16, Strata 3 and 4; Unit 20, Stratum 1), which usually dangled from the puente, and a portion of a cabestrillo (Fig. $4, g-i$ ) or rein chain (Unit 16, Stratum 3). Also found in the trash pits of Unit 16, Stratum 4, was the tab (Fig. 4,e) which connected the heel chain to a spur (Simmons and Turley 1980:110-111).

Two segments of branding irons were found, one in Area A, Stratum 3 (Fig. 5,n), and the other in Unit 16, Stratum 6 (Fig. $5, \mathrm{~m}$ ). Both were of the same plan or pattern. The branding iron fragment from Unit 16 shows the severe corrosion and scaling typical of heat damage on iron, while the other is in very good condition. The segment from Unit 16 still has a five centimeter portion of the tang which joined the brand itself to the handle. The specimen from Area $A$, Stratum 3 has a small portion of the tang in the same place. The lack of other tang segments, or scars where they had broken off, indicates that the branding iron segments formed only part of the design of the complete brand. This design is not known.

A portion of a gosne or snipe hinge was found in Unit 16, Stratum 3 (Fig. 4,f), of suitable size for a small chest or cabinet.

The Arms group contains gunflints, musket balls (Fig. 5,j,k), and modern cartridges and shells.

Included in the Construction group were hand-forged, machine-cut, and wire nails, fragments of mortar with plastered or whitewashed surfaces, and wood fragments. Hand-forged nails are probably from the Colonial occupation at Rancho de las Cabras. Cut nails were an Anglo-American product introduced to Texas after the establishment of the Republic of Texas. Wire nails date after ca. 1880. The three apparent cut nail fragments in Area A, Stratum 39 are probably either intrusive or are forged nail fragments, too corroded to be recognized as such. The recovery of 26 fragments of surface mortar in Area $A$, Strata 39, 43, and 44 imply that at least some portion of the jacals in this area were plastered and whitewashed.

\section{Discussion}

The artifacts recovered this season relate a number of things about life at Rancho de las Cabras. The horse harness and branding iron fragments are indicative of the cattle industry operating from this site; the rings and crucifixes 
indicate the close relationship between the site and the Catholic Church, and the other items are of the daily life in the compound. It is interesting to note that no artifacts have been found in the two seasons of work which would explicitly indicate the presence of women or children living at the compound, although historical records do indicate that several families, including women and children, did live here at least in the 1780s. Future work may tell us more about the home and family life of the occupants of Rancho de las Cabras.

The fact that the crucifixes and at least one of the finger rings found at Rancho de las Cabras are identical to those found not only in other parts of the San Antonio River valley, but also in other parts of the American frontier, such as Fort Michilimacinac, raises some interesting speculations. The most obvious conclusion is that religious activities in Texas were supplied, in part, from the same sources that supplied other frontier areas of the New World, areas that were not Spanish. In essence, the supplies in use at Rancho de las Cabras originated a very long way off; a world-wide system of trade supported the religious effort in Texas, of which the ranch was just one small component.

A more detailed and analytical discussion of the varieties of artifacts found in the San Antonio area, of which those at Rancho de las Cabras are a sample, is presented in Ivey and Fox (1983), along with a review of our present position on the chronological information contained in various ceramic classifications and in other artifact groups.

The presence of a large quantity of Goliad ware as the basic utility ware of the ranch and the significant amount of lithics in use show that a strong tradition of ceramic making and lithic utilization was continued at the site. The presence of these traditions are considered to be the result of the presence of a significant number of local or regional Indians as members of the population, and represent an Indian methodology for handling the basic tasks of daily life at the ranch. The ranch offers us a unique, self-contained laboratory for the study of the culture that resulted from the combination of regional Indian cultural traditions and an overlay of the more dominant of the cultural traditions of the Spanish frontier--a study, in other words, of acculturation.

\section{HISTORY OF RANCHO DE LAS CABRAS}

Mission Espada was one of the three Queretaran missions moved from east Texas and reestablished on the San Antonio River in March 1731 (Habig 1968:202). The College of Queretaro was one of the Franciscan missionary centers in New Spain and along with the College of Zacatecas established all the San Antonio missions (ibid.:25).

From 1731 until at least 1737 Mission Espada obtained needed cattle from the Queretaran missions of the Rio Grande, implying that the cattle of the mission were sti11 few in number unti1 about 1740 (Habig 1968:202, 204). By June 12, 1745 , the mission had 1150 cattle, 740 sheep, 90 goats, 31 horses, and 32 oxen (Ortiz 1745 microfilm roll 9 frame 1271) indicating that ranchland belonging to the mission was probably in use. It can be assumed, then, that Mission Espada began large-scale ranching activities in ca. 1740. 
Mission Espada was apparently in the process of acquiring legal title to this land in 1765: in testimony recorded on September 20, 1765, concerning the application by Mission San José for title to the ranchland called San Lucas, Bernabe Carvajal stated that the land applied for at San Lucas by Mission San José, combined with the land of Mission Espada, would not amount to much more ranchland than that already held by Missions Valero, San Juan, and Concepcion. The terms of the statement implied that the state of ownership of Mission Espada's land was in the same uncertain condition as that of Mission San José's land, which was still in litigation (GLO Spanish Archives Vol. 50:81). Title to the lands of Missions San Antonio de Valero, San Juan, and Concepcion had been granted in 1755 (Urrutia 0ct. 11, 1755 microfilm rol1 4 frame 52525254).

The earliest available description of Mission Espada's ranchlands was recorded (Valverde March 9, 1772 microfilm roll 3 frame 3605-3606) as part of the lawsuit between the citizens of San Fernando de Bexar and the missions of the river valley:

. . and on the part of the mission of Espada, it occupied the lands on the banks of the Medina River from the pass of the road from the Rio Grande up to the pass of Costales; and from this pass up to the Labor of Don Martin de Peña (adjoining the Medina River) the land which is occupied by Juan Joseph Montes and by the said Peña occupies the banks of the San Antonio River; and from the corner of the Labor of the said Peña up to Parrita Creek the banks of the San Antonio River are occupied by the lands of the Rancho of Espada, named las Cabras; and from the said creek of Parrita up to the Puertecito of Espanto Perros; from the Puertecito of Espanto Perros up to Blanco Creek the banks of the San Antonio River are occupied by the lands of the Delgados. . . .

This description indicates that the original ranchlands of Mission Espada extended much further north and west along the south bank of the Medina River than they did in 1787 .

Fr. Juan Morfi (n.d.:122) in December 1777, identified the boundary markers of Mission Espada's ranch at the crossing of the road from the Rio Grande over the Medina River: "A little further along... . on the right of the road are seen some rock on which are painted some crosses to indicate the boundary of the lands of the Mission San Francisco de Espada." By this date, however, Mission Espada had apparently lost its claim to this portion of its ranchlands (see below).

Don Pacheco (January 8, 1787 microfilm roll 18 frame 7 ) stated the effective limits of the ranch:

The mission of Espada may round up its aforesaid cattle from its rancho, called Las Cabras, within a direct line up the San Antonio River to the division between the rancho of Calbillo and that of Peña; from here to the headwaters of Padre Mariano Creek and Picoso Creek; from here in a direct 7 ine to Lucas Creek; from here to Santa 
Figenia Lake; from here in a direct line to the headwaters of the Los Gatos [Los Cortes Creek?]; from here in a direct 1 ine down to the Lake of Las Animas; and from here upriver to the same ranch of Las Cabras.

The land along the south bank of the Medina River west of the Montes and Peña ranches was no longer considered part of Rancho de las Cabras. This change was probably the result of legal action that made this property available to the general public sometime after 1772 (discussed below).

The last available description of Rancho de las Cabras was made by Governor Manuel de Salcedo (1809:5) when he stated:

The lands belonging to the Mission [extend] from [the Pass] of Chayupines as far as La Parrita Creek, for the entire bank of the River San Antonio, bounded on the east by the lands of the Delgados [Rancho Sab Cristobal de Espanto Perros]; on the south extending to the Atascosa River, from the west towards the east as far as the Rancho de Peña [Rancho San Yldefonso de Chayopin], Peña Creek serving as the boundary.

There are obvious difficulties with the directional statements, but the landmarks themselves are recognizable from the earlier descriptions. Salcedo added that this description was based only on unofficial documents or popular opinion, apparently there was no official deed on record.

The actual deed for the Rancho de las Cabras property is still unavailable, although it may well be in the unindexed portions of the Queretaran and Zacatecan microfilm archives of the 01d Spanish Missions Historical Research Library, Our Lady of the Lake University, San Antonio, Texas.

In 1756 the cattle of the ranch numbered 700, and there were 1950 sheep and 103 horses (Ortiz 1745 Vol. 1). Again, no ranch is specifically mentioned. Not until 1762 is there a mention of a ranch or its buildings. In this year, 1272 cattle, 4000 sheep and goats, 156 horses, and nine burros were on the ranch. It is described as having "un casa de piedra," a house or structure of stone, where the families lived who worked the ranch, and where the necessary tools and equipment were kept (Dolores 1961:259).

In 1772 all the Queretaran missions in Texas were turned over to the College of Zacatecas, and the Queretaran friars in turn assumed responsibility for the Jesuit missions in Sonora. The Jesuits had been forced to give up their missionary work in New Spain in 1767, and Queretaro was given the administration of their missions in the Pimeria Alta and Baja on July 8, 1767 (Bringas $1977: 38$ ).

As part of the transfer of the missions from Queretaran to Zacatecan, a very complete and detailed set of inventories and descriptions of the four Queretaran missions of San Antonio was compiled. The inventory for Mission Espada (Gumiel 1772 microfilm roll 15 frame 1371-1373; 1772 microfilm roll 10 frame 4224-4226) indicates a precise picture of the ranching facilities of the mission and its ranch: 
The mission has on this river at a distance of eight leagues [about 21 miles] a ranch for the protection of the herdsmen from the hostile Indians. It is enclosed by a wall of stone of a vara in width [about $85 \mathrm{~cm}$ ] and three varas in height [about $2.5 \mathrm{~m}$ ]. The said wall has a length, or circumference, of one hundred fifty eight varas [about $133.8 \mathrm{~m}$ ]. Item: It has two entrances with their gateways and gates, one towards the river and the other towards the plain. Item: It has on the inside four jacals of wood and thatch...

The inventory lists all the tools and other items in the ranch buildings that were the property of the church. One of the houses was used, at least in part, as a church or shrine with "a table for an altar, a platform under the table, and a small picture of St. Francis." The ranch had "an adequate corral of nailed and tied timbers, and four bull-pens of the same material with their barricades and gates for the large livestock and horses" (Gumiel 1772 microfilm rol1 15 frame 4224).

The inventory of 1772 (Gumiel 1772 microfilm roll 15 frame 4224-4425) 1ists the animals at the ranch at that time:

\section{Horse Herd}

First, 281 breeding mares

Two-year-old fillies: 51

Stallions for the aforesaid: 81

Two-year-old colts: 57

Two-year-old female mules: 15

Two-year-old male mules: 17

Young female and male mules to be branded: 41 head

Colts and fillies to be branded: 156

Burros which are mesos or mestizos: 8

Gelded burros: 3

Mules of age: 7

Domesticated Mules: 18

Ten female burros with their caballo padre

Six small branded burros

Domesticated male working horses: 75

\section{$\underline{\text { Pigs }}$}

First, 12 sows with three male pigs; an allotment of about twenty pigs kept separate for the Ranch.

\section{Sma11 Livestock}

The flock or sheep herd: 1,100

The Vaciada: 1,621

Goats: 22 


\section{Large or Bovine Livestock-At the Ranch}

First, eight oxen

Nursing cows (or milk cows): 150

Cows not nursing: 1,050

In addition to the corral complex at the ranch, there was a small farm planted with fifteen almudes (about two bushels) of corn, apparently for the use of the ranch. This labor was fenced with branches or poles in the manner called tixera (scissors).

The ranch, its corrals and buildings, its herds, and the people who lived and worked there, all were one end of a supply system; the other end of which was Mission Espada. The corrals and livestock-handling arrangements at Mission Espada, then, are the complement of those at Rancho de las Cabras.

In 1772, "next to the mission there is a corral of posts, nailed and tied, of a size for oxen and nursing cows; its bullpen [with] barricades and gates. Item: another of the same, more capacious, for enclosing cattle. Item: a small corral of posts, and in it a horse stable of the same material with its manger and roof of thatch" (Gumiel 1772 microfilm roll 15 frame 4221).

Elsewhere in the same inventory is the listing for "a small corral in which is enclosed sixty-eight goats, large and sma11, which are available for the restocking of the meat herd, and fourteen remain. Item: two gelded hogs being fattened are penned in their corral of wood, with a water trough" (Gumiel 1772 microfilm rol1 15 frame 4220-4221).

In addition, Mission Espada had a herd of 75 domesticated horses and one domesticated mule "for its necessary domestic chores" (Gumiel 1772 microfilm roll 15 frame 4225), and 40 yoke of oxen "for the cultivation of the fields... not counting others which have run into the woods, and 20 nursing cows" (Gumiel 1772 microfilm rol1 15 frame 4223). The inventory adds that the total number of cattle owned by Mission Espada, as estimated by those knowledgeable in this matter, "ought to be something more than three thousand head" (Gumiel 1772 microfilm roll 15 frame 4221 ).

A total of al1 the figures from the various documents results in 733 horses, 99 mules, 27 burros, 34 pigs, 2621 sheep, 90 goats, 88 oxen, and an estimated 3000 plus cattle for Mission Espada.

What were these large numbers of animals for? Cattle and other livestock were valuable only in so far as they provided materials of use and worth. Horses, of course, provided transportation from place to place, and the means for the ranchhands to monitor and collect the other 1ivestock. Sheep provided wool and meat, and goats supplied milk and meat. Pigs were meat sources, and mules and burros were riding and pack animals. Cattle supplied oxen for the heavy plowing. They also produced hides for all the necessary, innumerable leather goods used by the Spaniards; tallows and fats for lighting, lubrication, and soap; horn for carving and other uses; and, of course, meat. At Mission Concepcion during the early 1780s, four to six cattle were slaughtered per week for ca. 100-150 Indians (Leutenegger 1976:19). Mission Espada had a total of 174 Indians in 1772 and, therefore, would have been using about six cows per week, or about 300-315 per year. 
Ranch Development in the 1770s

In about 1770 when the missionaries of Espada, 1ike those of the three other Queretaran missions in the San Antonio River valley, had begun preparations to turn the mission over to the College of Zacatecas, a conflict arose between the San Antonio valley ranchers, missionary and secular, that would directly affect all the mission ranches.

The actual documentation of this legal battle is not available. Enough references to it exist, however, for a general outline to be formed of the terms of disagreement and its final outcome.

Apparently the secular ranchers felt that the mission ranches took up too much of the river valley, leaving insufficient good pastureland for the expansion of their own ranch holdings. In the 1772 Mission Espada inventory, for example, it was remarked that Espada was attempting to claim 24 square leagues of land (sitios de ganado major) for its ranchlands. This claim was before the Lord Special Judge as of 1772, and the question had not yet been decided "because of the unjust opposition of the [Canary] Islanders" (Gumiel 1772 microfilm roll 15 frame 4225). Since the recognized boundaries of Rancho de las Cabras includes something over 40 square leagues of land, this must have been a claim for an additional 24 square leagues. The "unjust opposition" referred to in the Mission Espada inventory was probably the countersuit entered by Don Vincente Alvarez Travieso and Don Juan Andres Alvarez Travieso (1771), representing the citizens of San Antonio to protest the size of the mission ranches. In this document, the Travieso's stated that the missions were claiming a total of 116 square leagues of additional land for their ranches. They alleged that this would put virtually all the land of the San Antonio River and its tributaries in the hands of the missions, leaving none for the expansion of the villa of San Antonio.

This file of suits and countersuits came before Don Diego Antonio Cornide y Saavedra, Special Judge of Sales and Distribution of Unappropriated Royal Lands and Waters. He reviewed the case: "By a document dated June 12th of this current year [1771], an appeal was made to the royal audiencia of this New Spain on the part of the missions. On the 12th of July [1771] a decision was rendered by the president and the oidores denying the appeal asked for and ordering the papers in the case returned to me for execution" (ibid.). On August 12, 1771, the Special Judge ordered an inspection and assessment of a11 the mission lands, and a report returned to him within sixty days.

Governor Juan de Ripperda, on February 20, 1772, suspended execution of this order "until His Excellency, the Viceroy. . . considers it wise to order me to carry it out. . . According to this file of documents, no further action was carried out. Nonetheless, some similar lawsuit on the part of the Canary Islanders succeeded at about this time. In the Archivo de la Secretaria de Gobierno of Saltillo is a petition by Fr. Jose Maria Salas of Mission San Antonio de Valero dated August 25, 1778, where in he requested that he be granted certain lands which had once been in use by Mission San Antonio de Valero's Rancho de 12 Mora, but which had been granted to private citizens in 1773. Fr. Salas reviewed the entire sequence of events whereby Mission San Antonio de Valero lost the use of this land. According to his testimony, Rancho de la Mora was 
established for Mission San Antonio de Valero in 1757. Fr. Salas states that in 1770 the Lord Special Judge of Lands and Waters determined the effective limits of the Rancho de la Mora, which were considerably smaller than those which were, according to Fr. Salas, in actual use. After this legal determination, the land south of the new limits of Rancho de la Mora were granted to Felipe de Luna and Joaquin de la Garza in 1773. Because they never fulfilled the necessary terms of occupation required for full legal ownership, Salas petitioned in 1778 for title to this land to be given to Mission San Antonio de Valero, since it had always been used by the cattle from the ranch. His petition was granted, and this land was added to the Rancho de la Mora in 1778 (Salas 1778 Vol. 4 Legajo 5:164-175).

It would appear from this that the Special Judge of Lands and Waters determined the effective limits of all the mission ranches in about 1770, and those lands that were found not to be in actual use were made available for distribution to secular ranchers. For Mission Espada this decision apparently resulted in the complete loss of the land west of the Montes and Peña ranches and the opening up of the northern portion of the land south and east of the Peña ranch to settlement by private ranchers on a leasing basis.

The Zacatecan Period--Ignacio Calvillo and the Origin of the Calvillo Ranch

Little documentation is available at present covering the history of Mission Espada's ranch from 1772 through about 1809. The ranch did continue to operate, as is shown by several documents, i.e., Bexar Archives microfilm roll 12 frame 205, Feb. 10, 1778-0ct. 31, 1778, states that the ranch served as the headquarters for the administration of a major roundup. More is known about the private rancher who leased the northern portion of the Rancho de las Cabras ranchland, Ignacio Calvillo.

Don Ignacio Francisco Xavier Calvillo first appeared in the records of San Antonio on November 26, 1760. He married Doña Maria Antonia de Arocha on this day (Leal 1976a:14). Antonia de Arocha was the daughter of Francisco de Arocha and Juana Curbelo, both Canary Islanders (Chabot 1937:167-168).

Don Ignacio's origins are somewhat more uncertain. He is not a Canary Islander, but was indicated in the San Fernando census taken December 31, 1795, as being Spanish and born in San Fernando, Spain (BA microfilm roll 26 frame 105-127). His birth date ranges between 1730 and 1745, according to which record is consulted, and in the records of his own marriage he is said to be the son of Don Jose Calvi1lo and Doña Lusgarda Lopez de Lara (Chabot 1937:167; Leal 1976a: 14). It is reasonable to suppose, therefore, that Don Jose Calvillo, his father, was a member of the Presidial Company of Bexar or one of the original nonmilitary settlers of San Antonio before the establishment of San Fernando de Bexar in 1731 .

Calvillo and Antonia de Arocha had four children: Francisco, born in 1762; María del Carmen, 1765; Juana, 1767; and Francisca, 1769 (Leal 1976b:9) Of these, Marỉa del Carmen Calvillo, born on July 9, 1765, was to eventually inherit the Calvillo ranch. 
Because of his marriage into a Canary Island family, Calvillo acquired certain rights, which he did not have as simply the son of an early settler or soldier. To use Calvillo's words: "Since I am married to Antonia de Arocha. . . our children, by reason of their descent from the first settlers, are therefore entitled by right and justice to any lands for which they pray. . . " (BCA Land Grant and Sales no. 116, Sept. 6, 1770:1). Based on this, he petitioned for and was granted a tract of 1 and, 80 varas on each side, west of and adjoining San Pedro Creek, immediately opposite the property owned by his wife's family, the Arochas. Because of an oversight in the proceedings, this property had to be regranted to Calvillo in 1773 and was then enlarged to $80 \times 109$ varas (BCA Land Grant and Sales no. 117, March 18, 1773:5). This apparently became the urban household of the Calvillo family. In 1790 Calvillo, his two married daughters, Maria del Carmen and Francisca, and their families are all listed consecutively in the census, probably indicating that they all 1 ived in adjacent households on Calvillo's tract of land (BA microfilm roll 21 frame 70). This pattern was also followed to some extent in the 1795 and 1804 censuses (BA microfilm rol1 26 frame 111, 113, 114; microfilm rol1 32 frame 839, 847).

Prior to 1778 Calvillo petitioned the governor of the province of Texas for "un Pedaso de tiera [d]onde mantener mi ganado" (GLO Spanish Archives Vol. 50: 187). He apparently received no answer to this petition, or at least no action on it, because on May 17, 1778, he again petitioned for pastureland (GLO Spanish Archives Vol. 50:187). He specified that he was asking for "un rancho en el paraje que 11 aman el paso de las mugeres entre medio del rancho de 1 as cabras y el rancho del challopin." Although we have no record of the land being granted to him, his petition was apparently accepted, because from this time on he appears as a landowner among the ranchers of the San Antonio River valley, and in a further petition submitted January 19, 1809, he referred to the fact that he had ".possessed.. . a ranch known as 'Paso de las Mujeres". . for about thirty-five years," or from about 1775 (BCA Mission Records 36).

Calvillo was granted full title to two sitios of pasture in 1809, land which may have included the Rancho de las Cabras buildings. The available file ended with a simple cover letter from Manuel Diaz, Alcalde of Mission Espada, stating that he was sending "the document which discloses the chain of title for the land in question" and requesting that the document be returned "when this transaction has been completed so that I may file it in the Archives" of Mission Espada. This was apparently done, since no claim of title is included. However, other documents in the files indicate some details of the history of Calvillo's ownership. For example, an earlier document was submitted by Fray Pedro Noreña, "apostolic priest and administrator of the said mission" of San Francisco de la Espada who had "examined the petition of Ygnacio Calvillo... I declare that the said Calvillo occupies the aforementioned 'Pasa de las Mujeres' which belongs to the ranch of this mission, which the permission of my predecessor the very reverend Father Fray Juan Botel10. . . ." Jose Flores, the Sindico Procurador of San Fernando de Bexar at the time, reported that the property had been "establecido por el interesado en calida[d] de prestamo por ser tierras mercenados a la Micion de San Franco de la Espada [confirmed to the interested party (Calvil10), in the form of a loan from the land granted to the Mission de San Francisco de la Espada]" (BCA Mission Records 36). The fact that the land was granted as a loan indicates that, although the new 
ranch limits of $\mathrm{ca} .1770$ permitted secular ranchers to acquire mission land, the missions still had some control over some of this land. In a parallel case, the subdeacon Don Manuel Sambrano on January 26, 1809, petitioned for four sitios of pasture around his ranch called La Purisima de las Animas (BCA Mission Records 37). He stated that "although in another time, this land was settled by the Mission Espada, it was abandoned about twenty years ago," or about 1790. This probably refers to the secularization of the mission 1 ands in 1794. The residents of Espada Pueblo objected to the 1 and being granted to Sambrano, but their claim was overruled by Governor Salcedo on March 4, 1809, and the 1and was granted to Sambrano on March 20, 1809. Obviously, therefore, some of the ranchlands of Mission Espada were still being disposed of in 1809. Calvillo's original claim, however, dates to the early 1770s, and appears to derive from a different set of legal and economical considerations altogether, rather than the disposal of secularized mission lands as occurred after 1794.

There can be no doubt that Calvillo was considered a legal landowner by all parties prior to 1809 . In the long and detailed set of agreements reached among the cattle-ranchers, religious or secular, on January 8, 1787, Mission Espada's territory for rounding up cattle was described as "from its ranch, called Las Cabras, in a straight line and up the San Antonio River to the 1 ine between the rancho of Calvi110 and Peña." November 8, 1791, an official 1 isting of ranches was prepared for Governor Manuel Munoz (Arocha 1791 microfilm roll 21 frame 872 ). Calvillo is listed as the "dueno del de Ntra. Senora de Guadelupe de las Mugeres," in the section of the report headed "siguen los qe se hallan Sin Gente y con Vieres [there follows those which are without people and with improvements]."

Calvil10, then, was a legal landowner, operating a ranch leased from part of the ranchlands of Mission Espada beginning in about 1773-1774, a procedure permitted by a legal decision against a11 the missions in about 1770-1771. He apparently maintained no permanent ranching facility on the property, but did have "improvements"; probably corrals, and perhaps the equivalent of bunkhouses for the men he would have periodically sent to round up his livestock. Calvillo himself, and his extended family, continued to live in San Fernando de Bexar.

This situation changed, probably beginning soon after 1810 with the first upheavels of Mexico's War of Independence. By 1814, he was living on the ranch, and there was an extensive complex of structures and a relatively permanent staff of small farmers. This group of buildings was located about $5.12 \mathrm{~km}$ north of Rancho de 1 as Cabras on the west bank of the San Antonio River (GLO Spanish Archives Vol. 31:99, Feb. 17, 1834). Some of the farmers 1ived permanently on portions of Calvillos' land, while others lived in San Fernando de Bexar and periodically visited their farm plots.

On April 15, 1814, Calvi110 was murdered by his own grandson, Ignacio Casanova, during a raid on the ranch buildings by Casanova and a group of others, including several Indians. A chest containing a quantity of money was stolen during this raid, and several of the jacal buildings of the ranch were set on fire. This misfortune for Ignacio Calvillo was of great benefit to us, because a detailed inquiry was carried out concerning the murder, and the testimony of most of the people present in or near the ranch at the time was placed on 
record (Basave microfilm rol1 53 frames 686-714, May 1, 1814). Fifteen persons were interviewed, and the descriptions of their activities before and during the day of the murder relates a fascinating and detailed look at the life and organization of a ranch in the last years of the Colonial period.

The testimony states that eight laborers were present who worked farms on the land of the ranch. Three of these were small farmers who had an arrangement with Calvillo for the use of his land for the growing of their own crops, probably on a leasing basis. The other five worked for the ranch itself. The ranch had a mayordomo, or foreman, who had been a tailor in San Antonio before he moved to the ranch. The foreman and the five ranchhands lived in the ranch compound itself, as did Calvillo and his wife. They had two household servants, man and wife. Living in the compound on a temporary basis were Ignacio's daughter, Maria Calvillo, and her physician. Visiting at the time of the murder was a pastor under the subdeacon Manuel Sambrano. The laborers who worked the fields leased from Calvillo did not live within the compound, but usually referred to themselves as "sleeping in the fields." This document reveals the intricate arrangements made between landowners, laborers, and sma 11 farmers during this period. Whether such arrangements were traditional in the valley, and whether the missions worked within these same traditions, cannot yet be answered.

\section{Maria Calvillo and the Calvillo Ranch}

After Calvillo's death the history of the ranch is vague for a number of years, until his daughter Maria del Carmen applied for a new title to the land in 1829. The intervening 15 years have a number of gaps. María had married Juan Lucas Gavino de la Trinidad Delgado in ca. 1781. They apparently 1ived in San Fernando de Bexar next door to Ignacio Calvillo, probably on his solat, or town lot, through 1804. In $\mathrm{ca} .1810$ she, and perhaps Gavino, moved into a house in Mission San Juan (BCA Mission Records 6, dated Dec. 27, 1823). In about 1813 Gavino and Maria separated, apparently because of the political strife which became chronic in San Fernando de Bexar at that time. In 1833 María stated that "her husband. . . died trying to defend the present Government System" (GLO Spanish Archives Vol. 31:75, June 26, 1833). In 1814 she stated that "por haver la desamparado su esposo, desde que entraron las tropas del Rey en esta Ciudad. . . [she had left her spouse, when the soldiers of the King entered into this city]" (Basave 1814 microfilm roll 53 frame 686). She moved to her father's ranch and was living there in 1814, when her father was murdered.

In 1823 Maria received title to her solar in Mission San Juan, and in 1828 she applied for a new title to her father's ranch, the old title having been taken from her, she said, "together with the chest; . . . during the time of the Spanish Government" (BCDR Vol. 2:375-378, Aug. 28, 1828). This may have occurred at the time of her father's murder in 1814, when a chest containing money was stolen from her father's ranch. She moved to the ranch permanently soon afterwards, and was living there in 1832 when she applied for additional land for her ranch (GLO Spanish Archives Vo7. 31:75, June 26, 1833). The remainder of Rancho de las Cabras was granted to Manuel Barrera in 1833 
(GLO Spanish Archives Vo1. 41:9, Nov. 29, 1833). In 0ctober 1835, three banegas (each 1.59 bushels) of grain and a cow were requisitioned from Maria at the ranch by J. H. Flores of the first Squadron de Campeones de la Libertad in the name of the Commanding General of Bexar (DRT Library).

In 1844 María began to sell pieces of her ranch (BCDR Vol. B2:316, Sept. 3, 1844), and in 1845 whe made out a will leaving her property to her two children, Antonio Duran and Maria Concepcion Gortari (BCDR Vol. J1:68, Aug. 10, 1851; see a1so WCDR Vol. 71:185-195). She stated in the will that she had been married to Gavino Delgado and had two children by him, both of whom were dead as of 1845. It is uncertain whether Maria Gortari and Antonio Duran were adopted or were her illegitimate children. Supporting the idea that one or both were adopted is a note in the 1804 census stating that she has one adopted child, age 12. Unfortunately this child was male, whereas in 1845 she indicated that her daughter Maria was "emancipated" while her son required a guardian, and was therefore somewhat younger than the 53 years that the 1804 census indicated he should have been.

Local tradition in the San Antonio River valley described Maria in the following terms: "She was a great beauty who forsook her husband and took over the personal management of her ranch, aided by various lovers. Although she bore her husband two children, she willed her estate to two other children fathered by her paramours" (Maguire 1972:10).

Maria died on January 15, 1856, at the age of 91 (SFA Burial Records 1856 \#1227). She had witnessed the major part of the cultural change in Texas, from the missions as viable institutions when she was a child, through the Mexican War of Independence and the Texas Revolution, to the entrance of Texas into the United States when she was 80.

\section{STRUCTURAL HISTORY OF RANCHO DE LAS CABRAS}

Based on this season of excavations at Rancho de las Cabras, a detailed outline of the changes and growth of the complex of buildings and other structures forming the ranch was more possible than at the end of the first season.

The Queretaran Period, 1755-1772

By 1762 a "casa de piedra" had been built at the ranch. No evidence of an early stone building has been seen on the site, and no mention of such a structure is made in the 1772 inventory. It is possible that the phrase "casa de piedra" referred to the stone enclosure wal1, although this is straining the meaning of the phrase. At any rate, some stone construction has been carried out by 1762, and a stone enclosing wall had been built by 1772 .

The enclosing wall, as described in the 1772 Inventario de Espada, was 158 varas in circumference or about $133.8 \mathrm{~m}$. The actual measurement of the interior circumference of the earliest form of the enclosing wall was $133.9 \mathrm{~m}$ (Fig. 1). This serves as both a confirmation of the identification for this earliest form of the wall as the Rancho wall of 1772 and striking evidence of the accuracy of measurement that could be achieved by Colonial methods. This accuracy has 
been seen with some consistency in Colonial documents--but this statement should be applied with caution, since occasional errors also are on record.

Indications of a jacal structure were found within the original wall in Area A. Area A produced the largest sample of information about the structural details of Rancho de las Cabras, but only a small portion of this excavated area extended inside the original wall, which was not known to exist at the time the unit was set up. This limits the data about the earliest plan and use of the complex.

The Zacatecan Period, 1772-1794

After 1772 a major change in the plan of the Rancho occurred. The period of this change may have been concurrent with major rebuilding at Mission Espada, which occurred in about 1780 according to our best available information (Ivey and Fox 1983). This is the same period as a major rebuilding effort at Mission San Juan, which is of interest because Mission San Juan began construction on a new church in ca. 1775, and the plan of this building included an octagonal sacristy strongly reminiscent of the various octagonal and octagon-derived structures built at Rancho de las Cabras.

Based on these considerations, it is suggested that the renovation of Rancho de las Cabras began during the period 1775-1780 as part of a general Zacatecan effort to upgrade the more secular aspects of the mission system, even though this was at the expense of the formal mission churches of Mission San Antonio de Valero, Mission San Francisco de la Espada, and to some extent at Mission San Juan Capistrano (for a more complete discussion of this, see Ivey and Fox 1983).

This renovation took the form of a sequential building program. The first construction involved the changing of the northwest face of the hexagonal Rancho compound to an acute angle. After this was completed, a hexagonal bastion was added to this corner. Probably at the same time, a bastion of similar plan was added to the obtuse angle on the southeastern corner of the complex. These bastions have no indication of a doorway or any other opening to their interiors in the surviving portions of the wall (see the discussion of Unit 20), and were probably reached by a ladder or stairs made of wood. Because of their size, it is very unlikely that they could have handled armament larger than a small swivel-mounted cannon, and may have been intended as musket positions with a clear line of fire along their respective wall pairs (Fig. 1). Such a plan would have left the northeastern face of the compound without covering fire. To provide this, the chapel complex may have had a musket position on its roof. The wall addition at this corner served to include the entrance of the chapel within the defensive wall of the Rancho and to form a churchyard for the building itself. Using this analysis, however, the flat face built on the extreme northeastern corner was unreasonable, since it gave cover from the lines of fire from both the chapel and the southeastern bastion. Perhaps the chapel position was high enough and close enough that this cover was of 1 ittle use to raiding Indians, and therefore considered a safe feature. No purpose can be suggested for it, however. 
The chapel was built onto the existing wall and northeast corner of the original fabric. It was the nature of the butt-joining of the apse of the chapel to the northeastern corner itself and the difference in wall thickness that led to the suggestion in the report on the first season's work that the west. wall of the chapel had originally enclosed that end of the compound and that the chapel was a later addition (Ivey and Fox 1981:41, 45). The thickness of the wa11 implies that the chapel had been somewhat higher than the original wall, the extra thickness being necessary to stabilize this added height. In ca. 1879 some of the walls at Rancho de las Cabras stood to a height of at least 15-20 feet (Menn n.d.:11-12), while the 1772 inventory states that the original wall was about $2.5 \mathrm{~m}$ high (about eight feet).

At about the same time, stone rooms were built into the northeastern corner of the compound, against the north wall and the chapel wall. This building would have served as a buttress for the thinner west wall of the chapel

building. Some portion of the north wall appears to have been rebuilt at the same time. A distinct change in stonework is visible in Stone Room 3 (Fig. 1) of the chapel building, which may be evidence of the construction necessary to tie a cross wall of the building into the north wall. The cross wall itself is shown as existing in 1902 (San Antonio Express 1934), but was apparently destroyed as part of a major treasure hunter's excavation in Stone Room 3 .

The stone building along the north wall was very likely covered with a flat roof of beams and a layer of earth, as was argued in Ivey and Fox (1981:1718). The chapel probably had the same construction, since no evidence has been seen of the numerous keystone-shaped blocks that would have been a major part of the fill of the interior of the chapel, had it been vaulted. A final determination of this will have to wait for the cleaning out of the chapel building. Crenellations, forming protective positions with firing slits, or embrasures, between, would probably have capped the chapel and both bastions. The bastions seem to have been filled with earth to some height above that which survives and may have had a flagstone or timber platform on top of this earth fill on which to stand, because the local earth is so sandy that wind moves it quickly.

As part of the construction work on the chapel, the original northeastern wa 11 was removed to grade. Most of this stone was probably reused in construction in this area, but would have been far from sufficient to allow the completion of the new complex. Additional stone would have been collected from quarry sites in the area. These sites have yet to be identified. Several wagon crews cutting and collecting stone and transporting it to the construction site would have been necessary for the construction of the new compound. In addition to this, a separate crew of workmen and masons, who would have laid out and dug the foundation trenches, built scaffolding, and trimmed and laid the stone, would have been working simultaneously with the stone gatherers. Auxiliary work such as carpentry for doors, window frames, roofing beams, and boards; as well as scaffolding for the construction; lime burning and mortar mixing for the finishing and surfacing material for the chapel; and perhaps a blacksmith shop for ironwork such as door and window hinges, latches, and nails would have been necessary for the new construction. It is likely that a squad of soldiers was supplied by the presidio at San Antonio for the protection of 
the work force during this exposed time. If so, references to this may be available in the Bexar Archives, and research into these documents for mention of such detached duty should be undertaken.

\section{The Northwestern Corner}

In Area $A$, a smal1 limeki1n was found. It was built into the foundation trench for the original northwest wa 11, which apparently had been removed prior to the building of the kiln. The time span for the removal of the northwest wall and the construction of the kiln can be seen from an examination of the kiln and its associated stratigraphy.

Traces of the earliest jacal structures are found just inside the original wall in the form of two rows of jacal posts approaching the original wall at slightly differing angles and with a separation of about $50 \mathrm{~cm}$ (Fig. 2). These are probably remnants of two episodes of jacal construction within the original wall. After the construction of the new northwest corner onto this face and the removal of the old wall, a new series of jacal structures were built, Jacal Rooms 1, 2, 3, and 4. This group of jacals appears to have gone through at least one change in plan between their construction and the building of the limekiln. This change involved the removal of the east wall of Jacal Room 1, which extended across the old stone foundation and the opening of a second gap or doorway in the southeastern corner of Jacal Room 2 . These changes may have been done as part of the work on the construction of the limekiln. At some point in the use of this room, two hearths were made on the floor, one on the lower occupation surface and two on the higher level. These later two hearths were shallow basinlike depressions about $60 \mathrm{~cm}$ across filled with fine gravel. These may not have been in use concurrently and appear to predate the operation of the limekiln.

The removal of the east wall of Jacal Room 1 may have been associated with the construction of the limekiln (Fig. 2). The flue depression was cut across the jacal trench, leaving only small traces of the trench itself. After the kiln began operation, Jacal Rooms 2 and 3 , at least, continued to stand for a time; traces of post molds of the wall structure extended up into the lower strata of debris from the limekiln. After an undetermined time, these jacals were removed, and the kiln operation continued building up a considerable deposit of 1 ime dust and burned sandy clay residue between the limekiln and the wa11.

This indicates that a period of construction and occupation of the jacals in this corner followed the building of the northwest angle, which in turn implies that the use for which the limekiln was built dated after this construction and occupation. If this limekiln was used to produce lime for the construction of the chapel and for mortaring, plastering, and whitewashing the interior, then this would indicate that the chapel was built sometime after the addition of the northwestern angle, perhaps as much as five or ten years later. The probable sequence of construction was as follows:

1. The extension of the northwest angle and the buildings of new jacals within it, which included the reconstruction of the gateway on the new north wall section. 
2. The construction of the northwestern and southeastern bastions. The stone rooms may have been built at this time.

3. The construction of the chapel, the northeastern extension, and the limekiln. This may have been part of the effort in the second phase of construction and, therefore, may have occurred five to ten years after the first phase of construction.

The Limekiln

The limekiln was probably of the type known as a "flare kiln," which was charged with fuel and limestone, fired, emptied of lime, and charged and fired again, as opposed to a "running kiln," which is charged with alternating layers of fuel and limestone, and fed more fuel and limestone at the top while burning continues. Burned lime is continuously removed from the bottom through a "draw hole" during the firing. The kiln at Rancho de las Cabras is not large enough to permit easy removal of lime from the side vent, and was probably charged and emptied from the top. Lindsay (1975:10), in his discussion of limekilns and their use in the 18th century, says:

. . the more sophisticated flare kilns were often subterranean except for the top of the wal1. . . . Most flare kilns were circular with a cylindrical interior, though some tapered slightly toward the base. . . . The best material for building kilns was brick, but this was expensive and most kilns were constructed of whatever stone was available. The most durable stones were granite and flint, but other hard stones such as sandstone were adequate. De Ramecourt recommended that mortar should not be used in those parts of the kiln exposed to the heat of the fire, but rather clay mixed with water. . . De Ramecourt also noted that in Provence, kilns were lined with well-beaten clay to protect the masonry. . . ."

The clay at Rancho de las Cabras apparently would not fire hard, and consequently the kiln had to be relined frequently. Much of the debris from the limekiln in Area A was a burned red sandy clay, probably cleaned out of the kiln and discarded. To perinit more control of the rate of firing, Lindsay (1975:10) says,

. . the opening at the base of the kiln, through which the fire was fed,... Was situated on the side opposite the prevailing wind, and often was further sheltered with a sunken approach. When the fire was started this opening was controlled by a door or masonry blocking which regulated the air supply to the fire. . . . A wind baffle was erected around the top of the kiln. In some kilns this was a fixed wa11; in others the baffle was a moveable wooden screen... O On top of the kiln itself the limestone was covered with large flat stones roughly set in clay, leaving a few holes for smoke to escape.

The stone wall of the compound immediately behind the kiln and the nearby jacal walls would have served as a wind baffle. Lindsay (1975:37) adds that the firing of the kiln produced steam, smoke, and fumes that were quite unpleasant, if not actually harmful, to nearby residents. The limekiln at Rancho de las 
Cabras, being about a vara $(85 \mathrm{~cm})$ in internal diameter, was small compared to those described by Lindsay (1975:10): "the internal diameter of De Ramecourt's kilns ranged from 6 pieds to 15 pieds [ 1.84 meters to 4.6 meters], though he recommended that smaller ones be built."

In association with the 1 ime making process, there would have been a 1 ime slaking pit of some sort, where the lime was slaked by being mixed with water, then stored until needed. No such pit has yet been clearly identified, but it is possible that Unit 13, excavated in the first season, located a portion of such a pit. The unit was excavated to a smooth white caliche or lime surface with a distinct slope and a basinlike curvature (Ivey and Fox 1981:28, 29).

A dependable water supply would have been needed for the slaking operation, as well as for all the other needs of the ranch. It is unlikely that this need could have been met by the carrying of water by hand from the river. Furthermore, the overall appearance of the site as having been intended for defense argues for a water supply within the compound. The most likely location for this is last season's Unit 5 (Ivey and Fox 1981:18), which 1ocated a smal1 circular depression with cracking of the earth within and around it indicating that some sinkage had occurred in the area. The diameter of this feature was $\mathrm{ca} .90 \mathrm{~cm}$. Further work should be done in this area.

\section{The Trash Pits}

The series of overlapping trash pits seen in Unit 16 were probably near and to one side of the original gateway to the surrounding fields mentioned in the 1772 inventory. These pits were capped by hard-packed earth and some rubble fill, which may have been intentionally laid over the depression of the pits to raise the surface to grade. The new northern gateway faced directly out onto this area, and this fill was probably put in to smooth the entrance. This would indicate a period of use for the trash pits of ca. 1760-ca. 1780. These pits would, then, contain a record of the material culture of the ranch up to its renovation and rebuilding. Similar trash pits containing materia? for the period ca. 1780-ca. 1800 may well be very close to the edges of these older pits on either side of the new gateway built in ca. 1780 .

\section{Other Associated Construction}

No trace has yet been seen of the extensive corral system associated with the ranch. Several rectangular anomalies to the north of the ranch have been seen in aerial photographs (provided by the Texas Parks and Wildlife Department). A surface examination of these anomalies was inconclusive. Future work should be directed towards the location of the corrals and a more intensive examination of the anomalous areas.

A small farming plot was also associated with the ranch. This may have been on the west side, where a low, loosely constructed masonry wall was found by the series of units designated 25. This appeared to be a very informal construction and may have served as a terrace or retaining wall. The area should be examined more extensively in future work. 


\section{CONCLUSIONS}

Units 16 through 25 were excavated during this season. Several of these were extended or multicomponent units. They were located so as to meet the requirements of the scope of work for this season and to generate questions for future investigation. In addition, an area five by six meters was opened in the northwestern corner of the compound to further examine the traces of a palisade structure discovered during the 1980 excavations.

The units explored the architectural and cultural remains of: (1) the northwest bastion; (2) the southeast bastion; (3) the northeast corner of the compound; (4) the facade of the chapel; (5) the area outside the southwestern corner of the compound; (6) the possible site of an early wall of the compound, later removed; (7) a suspected trash pit near the northwest corner; and (8) an associated possible gateway through the north wall.

Results of the excavations were as follows:

1. The outlines of the northwest and southeast bastions were cleared of rubble and mapped.

2. The walls of the northeastern corner were traced by the clearing of the rubble.

3. The facade of the chapel was located, and a test made for floors and other structural traces within the chapel structure. The evidence indicates that the front entrance and a major portion of the interior floor have been damaged or destroyed by treasure-hunters.

4. An irregular wall-like structure was traced extending towards the west from the southwestern corner of the compound. Insufficient evidence was seen to indicate what this was, but speculative uses such as a retaining wall for a small garden at this end of the fortifications, or a small wall as part of a corral structure, are reasonable hypotheses.

5. It was suggested at the end of the 1980 season that the original wall of the compound extended across the northeastern portion of the compound and was later incorporated as one side of the chapel. This hypothesis was proven correct. At the time of the construction of the chapel, a portion of the original northeastern wall was demolished; and the chapel and a new enclosing wa]1, the present northeastern corner, were built onto the compound.

6. The suspected trash pit turned out to be a series of overlapping trash pits with stratified fill. These were far too extensive to excavate fully as had been intended, and some portions of the fill contained sensitive material of great importance, such as large quantities of butchering debris. This butchering trash is potentially of great importance as a comparative population study of the Spanish frontier cattle industry. Other midden material from these pits document the discards of the material culture of the ranch through at least the first half of its occupation. 
7. The western edge of the suspected gateway in the north wall was located. The evidence now indicates that the trash pits were in use until this gateway was built, and then were filled to grade with dirt, trash, and stone to make a reasonably firm entranceway.

8. The area excavated in the northwestern corner revealed the complex nature of the structural history of Rancho de las Cabras. Of greatest interest was the finding of another original section of the compound wall cutting across this corner. As at the northeastern corner, the old wall was removed down to the contemporary ground level and a new one built, which enlarged the space within the compound. The bastion on this side was added after this wall extension was completed. The compound began as a six-sided structure, and the adding of the two corners later effectively reduced it to four sides while adding extra space on the interior.

A complex of palisade wall traces and hard-packed successive living surfaces were found within these walls. The earliest palisade traces were contemporary with the original walls, and later traces indicate at least two phases of palisade houses were built after the corner extension was completed. In addition, after the second phase of palisade construction, a limekiln was built into the old foundation remains of the original compound wall, using its stones for the sides of the kiln and its footing trench for the chamber. It is reasonable to suppose that this kiln was built to produce the lime used in the construction of the chapel on the northeastern corner.

\section{RECOMMENDATIONS}

As a result of this season's work, future work should include a complete stratigraphic excavation of the trash pit complex outside the northwest corner. The lower depositions, those including masses of articulated bone, should be excavated in such a manner as to have a photographic or drawn plan of the location of all major bone parts, with each bone given an individual identification number.

Thirty-square meters of the jacal complex in the northwest corner were excavated this year. An additional $60-\mathrm{m}^{2}$ area should be excavated to identify the pattern of buildings, changes through time, and function of the structures in this area.

Area testing of other portions of the compound is recommended for future work. The general nature of the various phases of construction in the northwest corner has been determined. Such an extended excavation should be carried out in some other part of the compound for a site-wide comparison of structures. This excavation should include a limited series (three or four units) of a $1 \mathrm{~m}^{2}$ or $1 \times 2 \mathrm{~m}$ tests placed at intervals along the walls. These units should be evaluated as to the range of structural and cultural evidence found in the area of each, and then a large area excavation should be conducted at the unit which is thought to show the widest range of structural, chronological, and cultural information. 
It is reasonable to assume that some burials occurred in the courtyard, in the chapel, or in both places. With this assumption in mind the entire final occupation surface in the "Chapel Courtyard" should be cleared. The burials would be easily identified as elongated oval disturbances in the surface of the courtyard. If such burials are found, they should be marked as to location, and a decision made as to whether they should be excavated. Policy should be established on the question of excavation of burials found on the site.

Unit 5, excavated in the 1980 season, found what could be the well of the ranch. Further excavations should be done to prove or disprove this. If the well is located, it should be completely excavated. The cultural debris in this well, accumulated as the ranch went out of use as a living site, would be an invaluable record of its last years.

There was a large corral complex associated with the ranch, apparently immediately adjacent to the ranch structure. Testing should be done in the areas around the ranch buildings in search of this complex. Anomalies seen to the northwest of the compound should be tested archaeologically by random excavations, a careful peeling away of the root-plowed upper earth in selected areas by machine, testing with remote-sensing devices, or a combination of these techniques should be used to locate any structures. The ranch existed because of the cattle, and therefore the study of the cattle and the methods of containing and manipulating them should be of as great an importance as the study of the people who lived here and did the work.

It should be obvious that most of these tasks are a complete season's work. Texas Parks and Wildlife should determine what questions need to be answered for the purposes of park establishment and initial interpretation, and which could be considered detailed studies to be saved for the future development of the park.

To aid in future excavations, the fencing of the site and the killing of the brush growing on the ruins should have top priority. As rubble is cleared, the remaining structural remains become more exposed to damage by roots and cattle. Additionally, all future excavation should have a large water supply if at all possible. A small towable water tank such as is used by the highway department would probably suffice. The earth at the site is too brittle and dusty when dry for proper excavation and recording, and the amount of water necessary to keep the excavation areas moist is larger than can be hand carried.

Locally available archival material is rather limited, so more extensive archival research is proposed involving archival material in Mexico. At present the archival collections in Mexico considered to have the greatest potential are those of the Franciscan Missionary Colleges of Zacatecas and Queretaro. Microfilms of some of the documents in these collections are available at our Lady of the Lake University, San Antonio, Texas, but it is estimated that these constitute less than $20 \%$ of the total holdings. The documentation of the construction and management of Rancho de las Cabras could well exist in these collections.

The potential for Rancho de las Cabras is very great. Rancho de las Cabras is one of the best preserved Colonial sites in Texas in terms of archaeology, and it is certainly one of the most important in terms of cultural and historical studies. It would not be excessive to say that it is a site which is critical to our understanding of the development of the San Antonio River valley. 


\section{REFERENCES CITED}

Alvarez Travieso, Don Vicente and Don Juan Andres Alvarez Travieso

1771 Land Claims: Protest of Vicente and Juan Andres Alvarez Travieso Against Claims of the Missions of San Antonio. Spanish material from various sources, Barker Texas History Center, The University of Texas at Austin.

Arocha, F.

1791 Document detailing ranches of the San Antonio River valley. Microfilm. Bexar Archives, Barker Texas History Center, The University of Texas at Austin.

Basave, J.

1814 Interviews taken after the murder of Ignacio Calvillo. Microfilm. Bexar Archives, Barker Texas History Center, The University of Texas at Austin.

Bexar Archives (BA)

Record of Roundup Licenses. Microfilm. Barker Texas History Center, The University of Texas at Austin.

Census, 1790. Microfilm. Barker Texas History Center, The University of Texas at Austin.

Census, December 31, 1795. Microfilm. Barker Texas History Center, The University of Texas at Austin.

Census, 1804. Microfilm. Barker Texas History Center, The University of Texas at Austin.

Bexar County, Texas

Bexar County Archives ( $B C A)$.

Land Grants and Sales. Originals and microfilm in Bexar County Courthouse, San Antonio, Texas.

Mission Records. Originals and microfilm in Bexar County Courthouse, San Antonio, Texas.

Bexar County Deed Records (BCDR)

Originals and microfilm in Bexar County Courthouse, San Antonio, Texas.

Bringas de Manzaneda y Encinas, Father Diego Miguel, O.F.M.

1977 Friar Bringas Reports to the King: Methods of Indoctrination on the Frontier of New Spain, 1796-97. Translated and edited by D. S. Matson and B. L. Fontana. The University of Arizona Press, Tucson, Arizona. 
Chabot, F. C.

1937 With the Makers of San Antonio. Artes Graficas, San Antonio, Texas.

Daughters of the Republic of Texas Library (DRT Library)

Smith collection. The Alamo, San Antonio, Texas.

Dolores, Father Mariano Francisco de los

1961 Relacion del Estado en que se hablan todas y cada una de las misiones, en el ano de 1762. In Documentes Para la Historia Eclesiastica y Civil de la Provincia de Texas o Nueva Philipinas, 1720-1779, edited by Jose Porrua Turanzas:245-275. Volume 12 of the Colección Chimalistic de Libros y Documentos Acerca de la Nueva Espana. Madrid.

Genera 7 Land Office (GLO)

Spanish Archives. Austin, Texas.

Sáenz de Gumiel, Juan Joseph

1772 Inventario de Espada. Zacatecas and Celaya microfilm. 01d Spanish Missions Historical Research Library, Our Lady of the Lake University, San Antonio, Texas.

Habig, M. A.

1968 The Alamo Chain of Missions, A History of San Antonio's Five old Missions. Franciscan Herald Press, Chicago.

Ivey, J. E. and A. A. Fox

1981 Archaeological Survey and Testing at Rancho de las Cabras, Wilson County, Texas. Center for Archaeological Research, The University of Texas at San Antonio, Archaeological Survey Report 104.

1983 Archaeological Investigations at Mission Concepción and Mission Parkway. Center for Archaeological Research, The University of Texas at San Antonio, Archaeological Survey Report 114 (in preparation).

Leal, J. 0., (compiler and translator)

1976a San Fernando Church Baptismals, 1731-1760. Vo1. 1. Typescript, Bexar County Clerk Office, Bexar County Courthouse, San Antonio, Texas.

1976b San Fernando Church Baptisma1s, 1761-1793. Vol. II. Typescript, Bexar County Clerk Office, Bexar County Courthouse, San Antonio, Texas. 
Leutenegger, Fr. Benedict, O.F.M.

1976 Guidelines for a Texas Mission: Instructions for the Missionary of Mission Concepción in San Antonio. 01d Spanish Missions Historical Research Library, Our Lady of the Lake University, San Antonio, Texas.

Lindsay, C. S.

1975 Lime Preparation at 18th Century Louisbourg. In Canadian Histonic Sites, Occasional Papers in Archaeology and History 12. National Historical Parks and Sites Branch, Parks Canada. Indians and Northern Affairs, Ottawa.

Maguire, J.

1972 This Is Texas: Women's Lib Pioneer. Texas Parade, June.

Menn, A. E.

n.d. The Floresville and Wilson County Story. Vertical files, Wilson County Library, Floresville, Texas.

Morfi, Fr. Juan Augustin de

n.d. Excerpt from Viaje de Indios y Diario del Nuevo Mexico. Translated by R. E. McDonald. San Antonio Conservation Society files, San Antonio, Texas.

Ortiz, Fray Francisco $X$.

1745 Razon de la Visita a las Misiones de la Provincia de Texas. Vol. 1. Edited by Vargas Rea, Mexico. Microfilm. Bexar Archives, Barker Texas History Center, The University of Texas at Austin.

Pacheco, Don Rafael M.

1787 Boundaries of the Roundup of 1787. Microfilm. Bexar Archives, Barker Texas History Center, The University of Texas at Austin.

Petersen, E. T.

1964 Gentlemen on the Frontier; A Pictorial Record of the culture of Michilimackinac. Mackinac Island State Park Commission, Mackinac Island.

Salas, Fr. Jose Maria

1778 Archivo de la Secretaria de Gobierno, Salti1lo, Coahuila. Saltillo Archives, photostats. Our Lady of the Lake University, San Antonio, Texas. 
Sa 1cedo, Manuel de

1809 Description of the lands of the missions of San Antonio. Dunn Transcripts: Archivo General de Indias, Sevilla Audencia de Guadalajara, 104-2-25. Barker Texas History Center, The University of Texas at Austin.

San Antonio Express

1934 Mission de las Cabras, Goat Mission, Crumpled Ruin Near Floresville. June 3 .

San Fernando Archives (SFA)

Burial Records. Microfilm available at the Catholic Chancery, San Antonio, Texas.

Schuetz, M. K.

1969 The History and Archeology of Mission San Juan Capistrano, San Antonio, Texas (Vol.2). Description of the Artifacts and Ethno-History of Coahuiltecan Indians. State Building Commission, Archeological Program Report 11.

Simmons, M. and F. Turley

1980 Southwestern Colonial Ironwork. Museum of New Mexico Press, Santa Fe, New Mexico.

Stone, L. M.

1974 Fort Michilimackinac, 1715-1781: An Archaeological Perspective on the Revolutionary Frontier. Publications of the Museum, Michigan State University, East Lansing, Michigan.

Urrutia, Don Toribio de

1755 Deed to the Ranches of Missions San Antonio de Valero, San Juan Capistrano, and Purisima-Concepción de Acuna. Microfilm. 01d Spanish Missions Historical Research Library, Our Lady of the Lake University, San Antonio, Texas.

Valverde, Fray Asisclos

1772 Depositions Concerning the Mission Lands of San Antonio. Microfilm. 0ld Spanish Missions Historical Research Library, Our Lady of the Lake University, San Antonio, Texas.

Wilson County, Texas

Wilson County Deed Records (WCDR)

Originals and microfilm in Wilson County Courthouse, Floresville, Texas. 


\section{APPENDIX \\ LITHIC ARTIFACT ANALYSIS FOR THE \\ 1980 AND 1981 SEASONS AT RANCHO DE LAS CABRAS}

Joseph H. Labadie

This section presents the laboratory analysis of the lithic artifacts recovered during Phase II excavations at Rancho de las Cabras. The lithic assemblage was divided according to a classification scheme using a processual model based on artifact attributes rather than a descriptive system based on morphology and planform. The reason for this choice in classification schemes was to be able to provide data in a form that allowed comparative interpretation of lithics recovered at other mission period sites in central and south-central Texas (Fox 1979; Scurlock and Powers 1975; Scurlock and Fox 1977; Clark 1978; Schuetz $1968,1969,1970,1973)$.

The classification scheme consists of morphotechnological classes and subclasses similar to those presented in Fox (1979). The classes may be considered as the products (artifacts that have been modified to function as tools) and byproducts (debitage) of the lithic processes at Rancho de las Cabras. Examination by a hand-held lense aided in providing additional data.

\section{Cores (17 specimens)}

The term core may be applied to any nodule or cobble from which a flake(s) has been removed. Within this category, $94 \%$ of the cores were produced from stream-worn chert cobbles that are similar to chert found today in the nearby San Antonio River channel (James Ivey, personal communication).

The size of the cores range from $8-35 \mathrm{~cm}$. The degree of reduction of each varies: three specimens have had one flake removed; one specimen has had two flakes removed; and 13 specimens have had four or more flakes removed. Three cores have had flakes removed unidirectionally. Two cores have flakes removed from opposing platform areas, and 12 cores have multidirectional removals. None of the artifacts within the sample have any signs of thermal alteration, and only two are completely devoid of cortex. There are 14 cores with corticate platforms and three with decorticate platform areas. After examination with a hand-held lense, three of the cores may have functioned as core tools.

\section{Microwear Analys is}

Specimen 1, Area A, Unit 39 has been unifacially trimmed along one lateral edge producing a subtriangular profile in cross section. There is a general smoothing of the scar ridges with some step and/or hinge flaking. Few identifiable striations could be found on this lateral edge; those identified, generally ran parallel to the long axis of the artifact. This working edge showed few signs of functioning in a chopping and/or pounding motion; rather, the edge damage appears to have been produced in a scraping and/or sawing motion. 
Specimen 2, Unit 24, Stratum 1 is almost completely corticate, a quartermoon in planform, with the right lateral edge spokeshaven in edge plan. Unifacial spalling along this edge may have resulted from the steep edge angle $\left(60^{\circ}\right)$ coming in contact with a relatively hard material. The scar ridges show few signs of smoothing, indicating the tool was discarded after it served the purpose for which it was made.

Specimen 3, Area $A$, Unit 43 has the ventral surface on the right lateral edge unifacially reduced which produces the bit edge on the artifact. Edge damage consists of hinge-terminated flake scars with scar ridges smoothed which produces a dull edge. No other areas of utilization were noted.

Flakes and Chips (723 specimens)

Flakes and chips comprise $91 \%$ of the entire 1ithic assemblage. Flakes are defined by the presence of some portion of the original platform that detached it. The sample was sorted into categories based on the amount of cortex present on the dorsal surface area with further subdivision within these categories based on platform type. Chips are defined by the absence of a platform and were sorted into categories based solely on the amount of cortex the chip retained.

Each category of flakes (primary, secondary, and tertiary) was divided into subdivisions based on platform type (corticate, single faceted, and multiple faceted). Each of these subdivisions was further divided into modified (trimmed and utilized) and unmodified, and microwear analysis was confined to modified specimens.

Each category of chips was divided solely on the amount of cortex present (corticate, partially corticate, and decorticate). Each subdivision was further divided into modified (trimmed and utilized) and unmodified, and microwear analysis was confined to modified chips.

\section{Primary Flakes (59 specimens)}

Primary flakes are produced as an initial removal from a cobble and/or core. Because of this, all primary flakes have unprepared cortex platforms with cortex covering the entire dorsal surface of the flake removed. Subdivisions within this category are unmodified, utilized, and trimmed.

Unmodified (30 specimens): This subdivision consists of primary flakes that show no sign of edge modification and are considered by-products of the 1 ithic reduction sequence or debitage (Fig. 6,b).

Utilized (17 specimens): Utilized flakes exhibit wear in the form of minute chipping and nibbling along edge(s), a result from the flake's use as an unprepared tool (Fig. 7,a). The location of utilization breaks down as follows: six specimens have lateral modification only, 10 specimens have both side and end utilization, and one specimen is utilized distally only. Three specimens have natural projections which form a beaked edge plan (one distal, two lateral) with nibbling and/or chipping on the beaks of all three. 
49
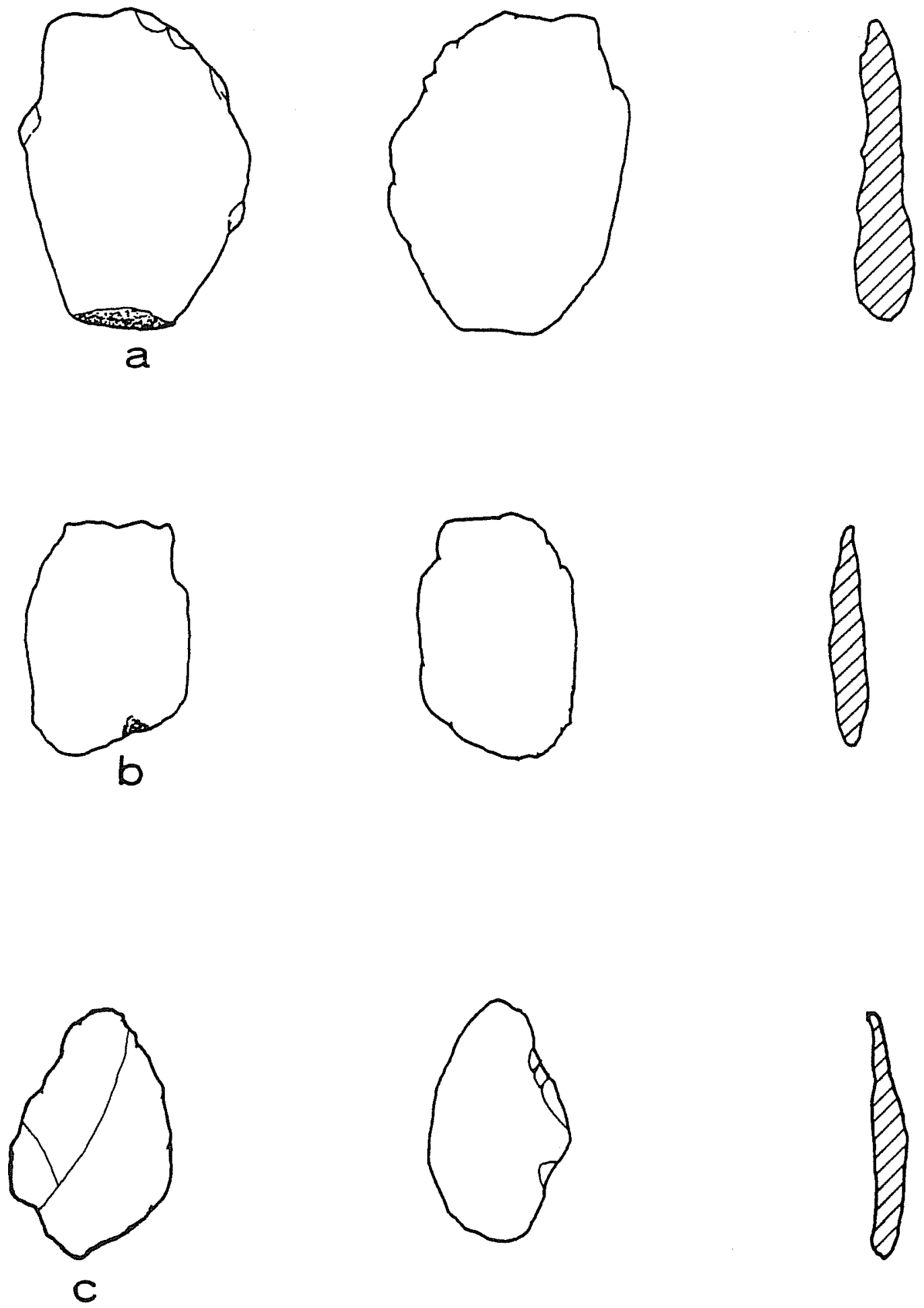

Figure 6. Primary and Secondary Flakes. a, primary flake, trimmed, Area A, Unit 39; b, primary flake, unmodified, Area A, Unit 43; c, secondary flake, cortex platform, utilized, Unit 16, Stratum 3 . 

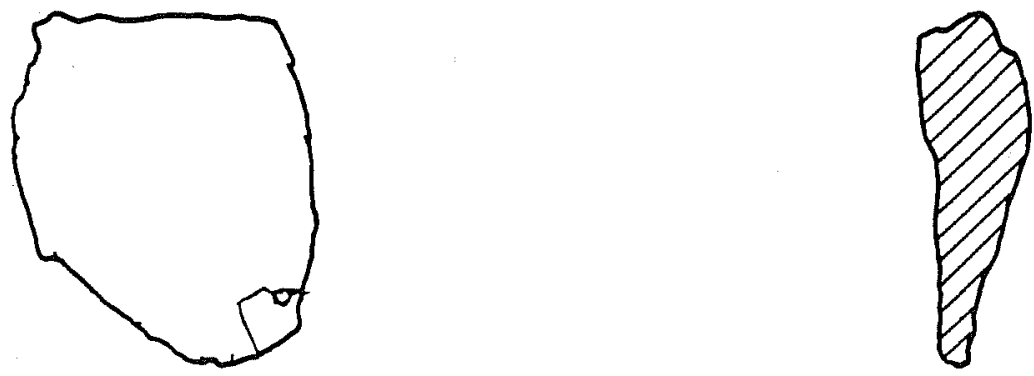

a
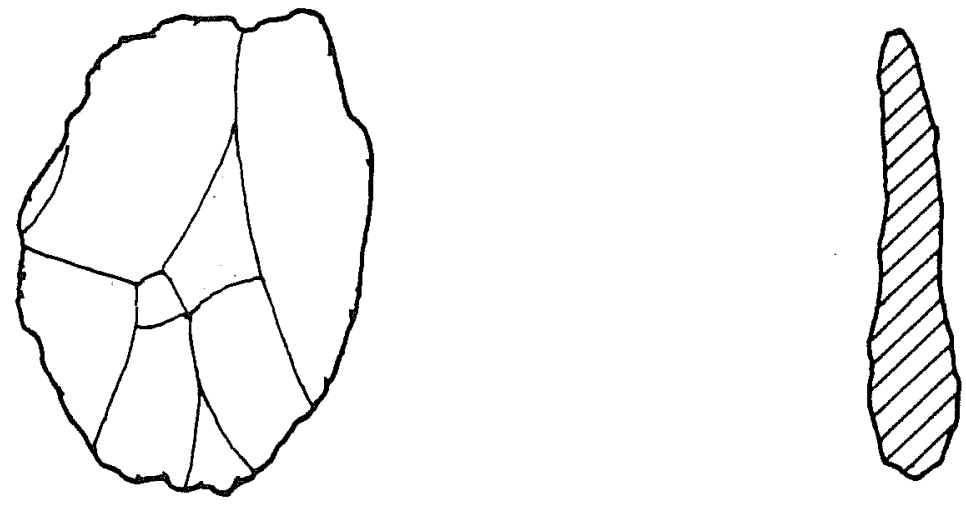

b
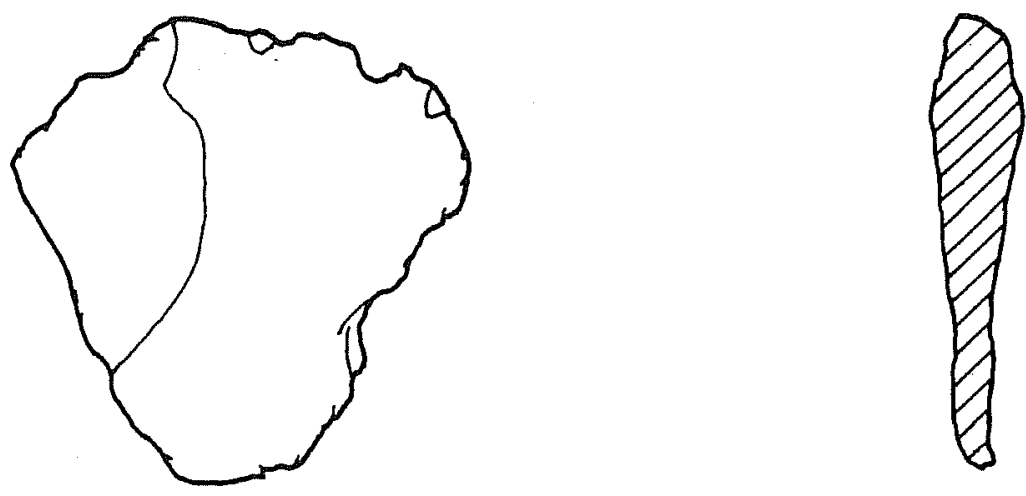

C

Figure 7. Flakes. a, primary flake, utilized, Unit 19, Stratum 1; b, secondary flake, cortex platform, trimmed, Unit 16, Stratum 10; c, secondary flake, multiple facet, trimmed, Unit 16, Stratum 4. 
Trimmed (12 specimens): Trimmed flakes have edge(s) which have been altered by the removal of small flakes either unifacially or bifacially (Fig. 6,a). The degree of modification to the edge is such that the flake still retains a portion of the original interior/exterior surface and is still identifiable as a flake. The location of the trimming is evenly split: four specimens, end only; four specimens, side only; and four specimens, end and side. None of these flakes show signs of thermal alteration. Within this subdivision, two flakes have scars whose removal was designed to thin particular areas, and three flakes have a beaked edge plan (two distally, one laterally).

\section{Microwear Analysis}

Specimen 1, Area A, Unit 43 has a splayed planform. Nibbling and nicking from utilization is present on the lateral edges with trimming (unifacial) isolated to the right lateral edge. Flake scar ridges are generally smoother with no discernible striations or polish.

Specimen 2, Unit 6, Stratum 9 has a thick bulbar end consistent with one produced by heavy percussion. The artifact has been unifacially trimmed on both lateral edges as well as the distal edge. The dorsal surface (distal area) exhibits both minor and major spalling with small, hinge-terminated flake scars primarily confined to the ventral surface. Polish and striations were absent on the scar ridges with a general smoothing and some nicking present.

Specimen 3, Unit SC, Stratum 3 has an elongated planform with utilization confined to the right lateral edge only. Wear along this edge is in the form of minute chipping and nibbling; trimming was absent.

Specimen 4, Area A, Unit 43 has an ovate planform produced by unifacial trimming. Wear is confined to the distal and left lateral edge only. Scar ridges on the distal portion exhibited the greatest amount of smoothing but with no polish or striations readily visible or identifiable.

Specimen 5, Unit 16, Stratum 7 was produced by heavy percussion with evidence of utilization confined to the upper margin of the right lateral edge. Wear is characterized by nibbling and/or nicking with no signs of trimming present.

Specimen 6, Area A, Unit 43 was also produced by heavy percussion with no signs of trimming. Edge damage due to utilization is present on the distal and right lateral edge only in the form of nibbling and minute chipping.

\section{Secondary Flakes (135 specimens)}

Secondary flakes are flakes that retain cortex somewhere on the dorsal surface with the amount of cortex present varying considerably. At least one flake facet is also present on the dorsal surface which was formed by a previous flake removal. This category was divided into subdivisions based on platform types (cortex, single faceted, and multiple faceted). These divisions were further divided into unmodified, utilized, and trimmed. 
Cortex Platform (74 specimens)

Unmodified ( 15 specimens): These secondary cortex platform flakes have no signs of modification (Fig. 9,e).

Utilized (51 specimens): The location of utilization breaks down as follows: side only, 30 specimens; end only, five specimens; end and side, 16 specimens. Two specimens have beaked edge plans (both laterally) with nicking and/or nibbling on both projections (Fig. 6,c).

Trimmed (eight specimens): The location of trimming breaks down as follows: one specimen, end only; two specimens, side only; five specimens, end and side. Within this division, one flake has flake scars whose removal was designed to thin a specific area, and two specimens (Figs. 7,b; 8,c) have trimmed (unifacial) beaked edge plans (one distal, one lateral).

\section{Single Facet Platform (31 specimens)}

Unmodified (five specimens): No sign of modification was seen on five specimens.

Utilized (14 specimens): The location of utilization breaks down as follows: 10 specimens, side onty; one specimen, end only, three specimens, end and side. None of the specimens has a beaked edge plan or has signs of thermal alteration (Fig. 8,a).

Trimmed (12 specimens): The location of trimming breaks down as follows: eight specimens, side only; one specimen, end only; three specimens, side and end. Two specimens have beaked edge plans (one bifacial, one unifacial), and four specimens have flake scars whose removal was designed to thin specific areas.

Multiple Faceted Platform (30 specimens)

Unmodified (five specimens): Five multiple faceted platform secondary flakes have no signs of modification.

Utilized (13 specimens): The location of utilization breaks down as follows: eight specimens, side only; one specimen, end only; four specimens, end and side. None of the specimens in this group have a beaked edge plan.

Trimmed (12 specimens): The location of trimming breaks down as follows: two specimens, end only; four specimens, side only; six specimens, side and end. Within this division, one specimen has flake scars whose removal was designed to thin a particular area, and one specimen has a beaked edge plan (Figs. 7,c; $9, a)$. None of the artifacts has evidence of thermal alteration. 

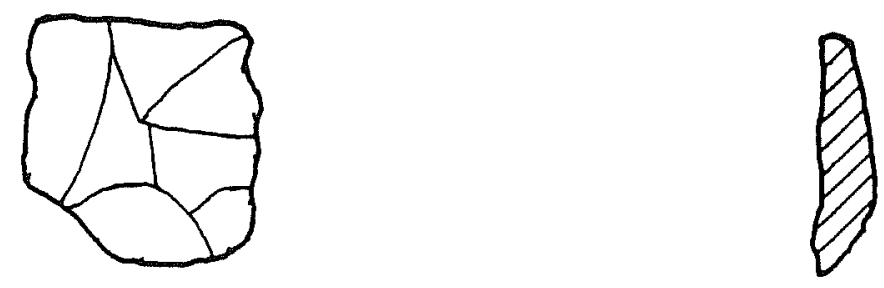

a
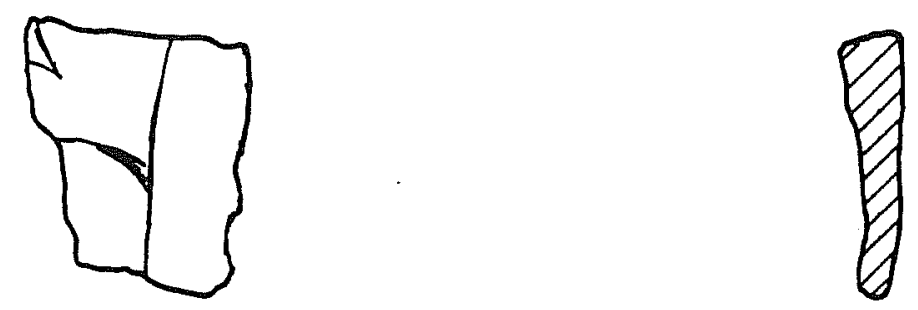

b
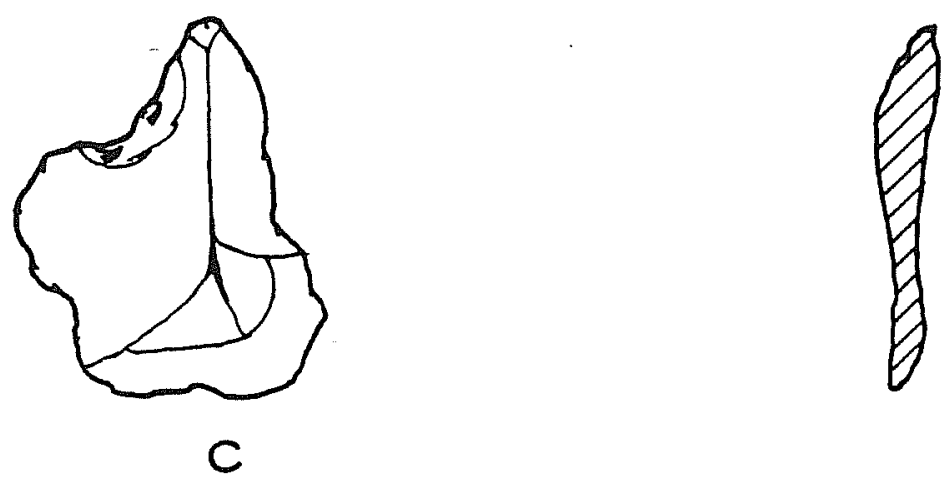

Figure 8. Flakes and chips. a, secondary flake, single facet platform, utilized, Unit 19, Stratum 1; b, chip, decorticate, utilized, Unit 24, Stratum 1; c, secondary flake, cortex platform, trimmed, Unit 15, Stratum 4. 


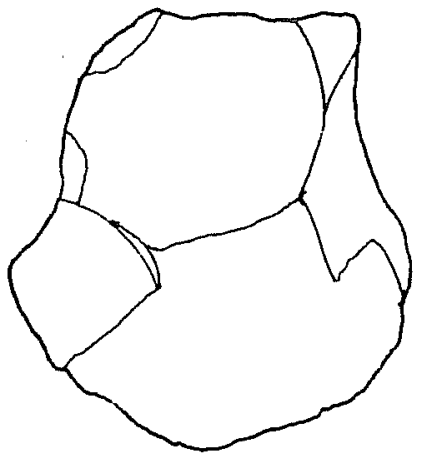

a

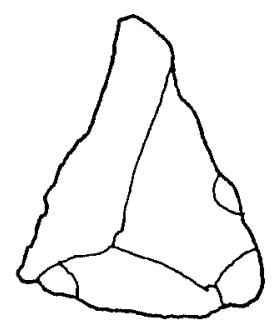

C

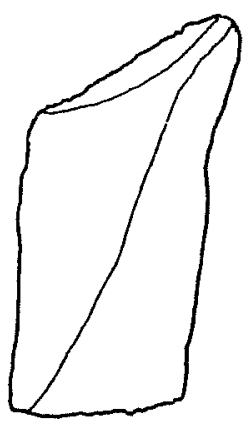

e
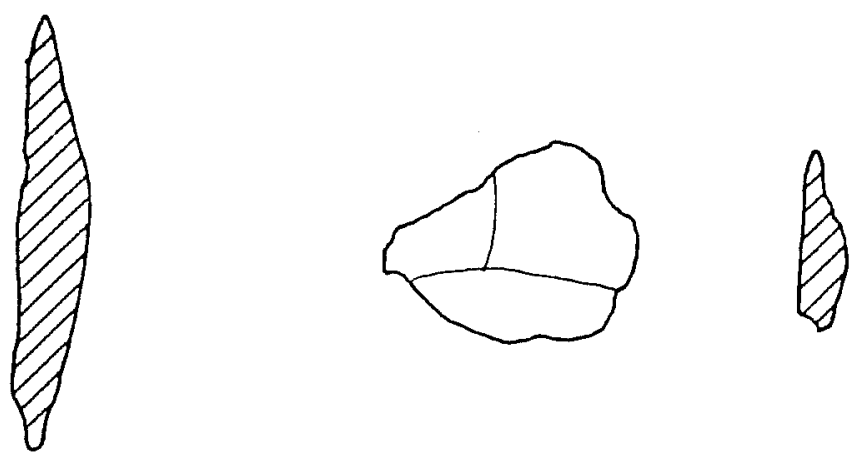

b
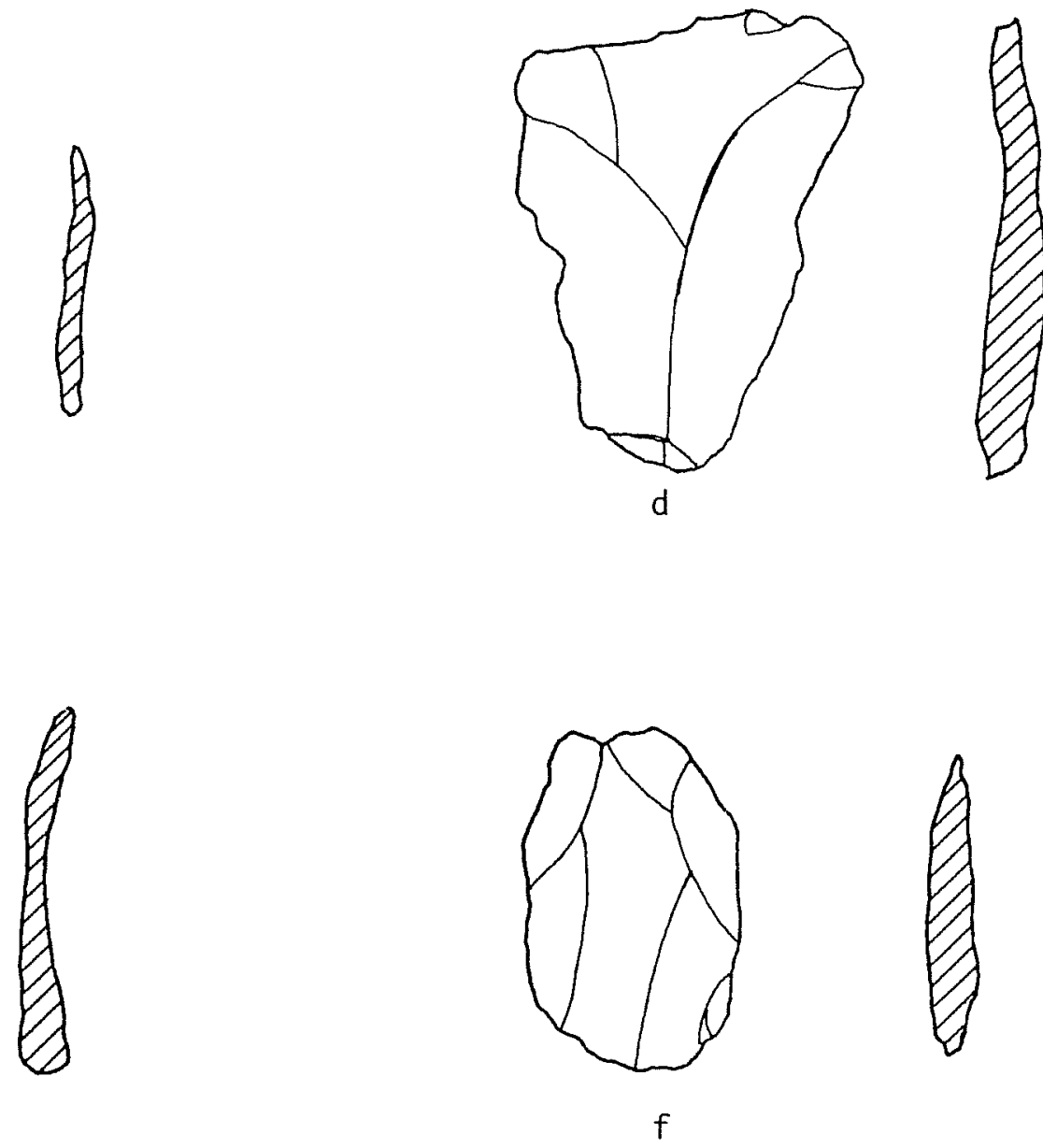

f

Figure 9. Secondary and Tertiary Flakes and a Chip. a, secondary flake, multiple facet, trimmed, Unit 16, Stratum 4; b, chip, partially corticate, utilized, Area A, Unit 44; c, tertiary flake, multiple facet, trimmed, Area $A$, Unit 2; d, tertiary flake, single facet, utilized, Area A, Unit 39; e, secondary flake, cortex platform, unmodified, Unit 19, Stratum 1; $f$, tertiary flake, multiple facet, trimmed, Area A, Unit 11. 
Tertiary Flakes (78 specimens)

Tertiary flakes represent removals from the decorticate areas of cores, flakes, or bifaces. The distinct feature common to all tertiary flakes is the total absence of cortex. Tertiary flakes that had cortex platforms or cortex in the area of the platform were placed with secondary flakes, cortex platform division.

Single Facet Platform (42 specimens)

Unmodified (26 specimens): Within this group, one flake shows evidence of thermal alteration which appears to have occurred after its removal from a core.

Utilized (12 specimens): The location of utilization breaks down as follows: eight specimens, side only; three specimens, end only; one specimen, end and side. One specimen has three beaks and/or projections along the distal edge which are formed by the scar ridges produced by previous removals (Fig. 9,d).

Trimmed (four specimens): The location of trimming breaks down as follows: three specimens, side only; one specimen, end and side. One specimen has flake scars whose removal was designed to thin a specific area. Only one specimen has a trimmed (unifacial) beaked edge plan on a lateral edge (Fig. 10,f).

Multiple Facet Platform (36 specimens)

Unmodified (10 specimens): Ten specimens are not visibly modified.

Utilized (17 specimens): The location of utilization breaks down as follows: 12 specimens, side only; two specimens, end only; three specimens, end and side. None of the specimens has beaked edge plans or evidence of thermal alteration (Fig. 10,e).

Trimmed (nine specimens): The location of trimming breaks down as follows: one specimen, end only; six specimens, side only; two specimens, end and side. Three specimens have flake removals designed to thin areas; two specimens (Fig. 9,c,f) have beaked edge plans (one distal and one lateral, both unifacially trimmed).

Chips (451 specimens)

Chips are flake fragments which do not possess striking platforms or bulbs of percussion. They were sorted into categories based solely on the amount of cortex present (corticate, partially corticate, decorticate). Each of these subdivisions was further divided into modified (trimmed and utilized) and unmodified with microwear analysis confined to those artifacts that were either trimmed or utilized. 
56

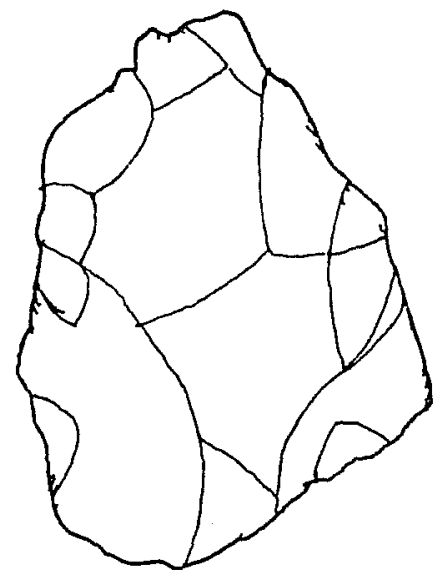

a

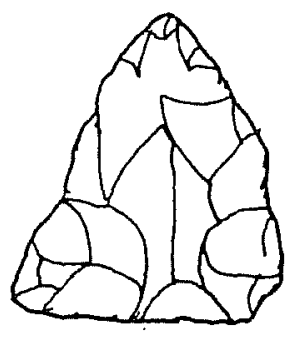

$\mathrm{C}$

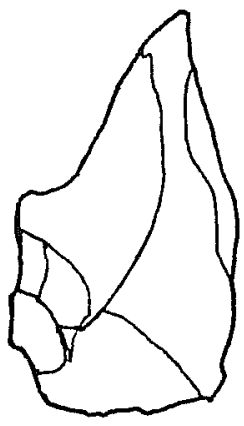

e
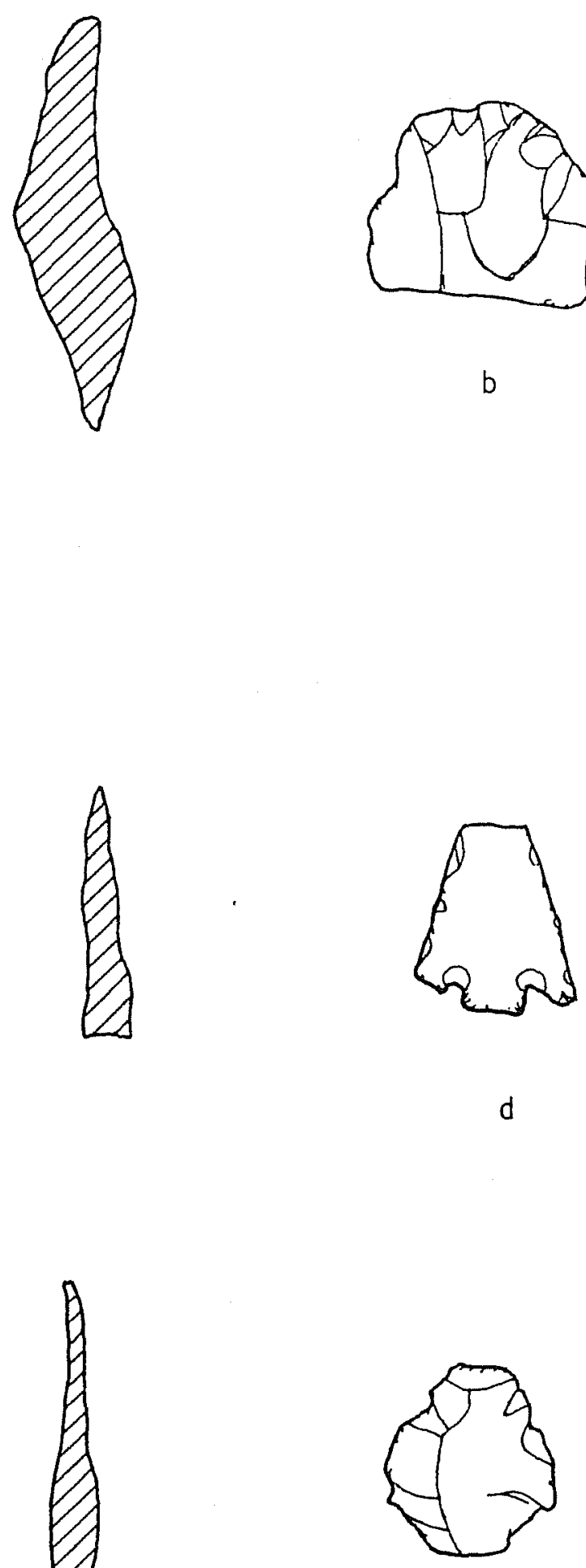

d

$f$

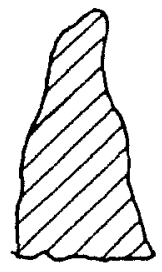

b
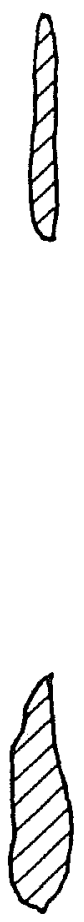

$f$

Figure 10. Bifaces and Tertiary Flakes. a, thick biface, Specimen 6, Area A, Unit 3; b, thick biface, Specimen 1, Area A, Unit 4; c, thin biface, Group I, Specimen 2, Unit 16, Stratum 4; d, thin biface, Group I, Specimen 3, Unit 16, Stratum 3; e, tertiary flake, multiple facet, utilized, Unit 19, Stratum 1; f, tertiary flake, single facet, trimmed, Area $A$, Unit 1. 
Corticate (75 specimens)

Unmodified (41 specimens): These corticate chips have no signs of modification. Utilized (26 specimens): These corticate chips have been utilized.

Trimmed (eight specimens): Three specimens have flake scars caused by flake removal to thin specific areas; no specimens have beaked edge plans. Three specimens have been trimmed side only, and five specimens end and side. None of the corticate chips has evidence of thermal alteration.

\section{Partially Corticate (204 specimens)}

Unmodified (107 specimens): The specimens have no signs of modification.

Utilized (85 specimens): These specimens have some signs of utilization (Fig. 9,b).

Trimmed (12 specimens): None of the specimens has thinned areas. Three specimens have beaked edge plans (a11 occurring laterally). Five specimens are trimmed side only (all bifacially); one specimen, end only; and six specimens, end and side. Five of the chips show evidence of thermal alteration.

Decorticate (172 specimens)

Unmodified (86 specimens): These specimens have no signs of modification.

Utilized (65 specimens): These decorticate chips have signs of utilization (Fig. 8,b).

Trimmed (21 specimens): None of the specimens show signs of attempts to thin specific areas. One specimen has a beaked edge plan (distal). Six specimens have been trimmed side only; three specimens, end only; 12 specimens end and side. Five of the chips show evidence of thermal alteration.

Bifaces (32 specimens)

Each specimen within this category exhibits bifacial flaking and represents $4 \%$ of the entire lithic assemblage. This category is divided into two groups according to thickness. Thick bifaces are greater than $1.3 \mathrm{~cm}$ thick, while thin bifaces are less than $1.3 \mathrm{~cm}$ in thickness. Thin bifaces are divided into four groups. Metric attributes are given in millimeters when appropriate with the following abbreviations: $T=$ thickness, $W=$ width, $L=1$ ength, $E A=$ degree of angle.

Thick Bifaces (seven specimens)

Specimen 1, Area A, Unit 4 is a distal portion of a bifacial tool made of petrified wood and is high backed in cross section (Fig. 10,b). Bifacial 
trimming occurs on both lateral and distal (bit) edges. The proximal portion of the artifact displays a roll-snap break with evidence of utilization after the break occurred. Edge damage (present on all edges) consists of hingeterminated flakes with some spalling (distal). Microwear analysis revealed that there were tiny spalls on the distal edge with some spalls having correspondent spalling on the distal and/or ventral surface. Striations were present on some ventral scar ridges but with no distinct directionality. The metric attributes are as follows: T: $2.13 ; \mathrm{W}: 2.81 ; \mathrm{L}: 4.84$.

Specimen 2, Unit 17, Stratum 3 is a medial section of a thick bifacial tool that exhibits a roll-snap break at both ends. The left lateral edge shows the heaviest wear with minor spalling and some hinge-terminated flaking. It is biconvex in cross section. Metric attributes are as follows: T: 1.40; $W: 3.16 ; \mathrm{L}: 3.22$.

Specimen 3, Area A, Unit 3 is ovate in planform and approaching parralelogram in cross section. Cortex is present on the dorsal surface. All edges have step and/or hinge flaking type of wear with edge rounding and a resultant dul1 working edge. Metric attributes are as follows: $T: 1.61 ; \mathrm{W}: 3.91$; L: 5.16 .

Specimen 4, Unit 16, Stratum 2 has an elongated ovate planform which is almost high backed in cross section. The dorsal surface is heavily patinated (which apparently has occurred since the original modification). There are several flake scars on the dorsal surface which reveal the underlying matrix of gray tan chert. The distal and left lateral edges have been bifacially trimmed forming regular edges. Damage to these edges consists of hinge-terminated flakes with the resultant edge dull to the touch. Metric attributes are as follows: $T: 1.44 ; W: 2.85 ; L: 3.72$.

Specimen 5, Unit 16, Stratum 4 is what is commonly called a Clear Fork tool made of petrified wood. It is biconvex in cross section with the bit edge formed by unifacial trimming. The left lateral edge forms a regular edge while the right lateral forms a straight edge. Microwear analysis revealed that most flake scars on the dorsal surface were predominantly hinge terminated. From replicative experiments (Ode11 1981; Hester, Gilbow, and Albee 1973), this pattern of surface alteration is consistent with those produced by the planar (nonconvex) surface leading and the convex surface trailing in a motion towards the operator in a scraping motion. The metric attributes are as follows:

$\mathrm{T}: 1.57 ; \mathrm{W}: 3.36 ; \mathrm{L}: 7.51$.

Specimen 6, Area A, Unit 3 is a distal fragment of a thermally altered biface (Fig. 10,a). There is a roll-snap break on the proximal edge, and the interior surface is consistent with both the dorsal and ventral surface, indicating the tool was broken before it was thermally altered. The metric attributes are as follows: $T: 1 . \overline{94} ; W: 3.92 ; L: 3.44$.

Specimen 7, Unit 2 has an irregular planform, high backed in cross section, and cortex on the dorsal surface. The bit edge has an edge angle of $60^{\circ}$ with step and/or hinge-terminated flakes concentrated in the middle of the bit. Scar ridges on the right lateral edge have been dulled by abrasion. The dorsal surface is covered with irregular, hinge-terminated scars and other unusual depressions and rises. The metric attributes are as follows: T: 1.55; $W: 2.85 ; L: 2.40$. 
Thin Bifaces (25 specimens)

Thin bifaces do not exceed $1.3 \mathrm{~cm}$ in thickness and were divided into four groups: Group I, Prehistoric; Group I I, Ovate planform or beaked planform; Group III, Guerrero points; Group IV, Miscellaneous.

Group I (four specimens)

This group of thin bifaces consists of artifacts that are believed to belong to the Archaic or Late Prehistoric era. Among these specimens, a Perdiz point, two parallel-sided point fragments, and a Clear Fork tool (described with Thick Bifaces), appear to be the only diagnostic artifacts; the others appear to be similar in fashion to artifacts attributable to the Late Prehistoric era.

Specimen 1, Area A, Unit 2 is a distal fragment of a bifacial point which is biconvex in cross section and exhibits a roll-snap break on the proximal edge. The lateral edges are almost parallel sided with the scar ridges along these edges smoothed, producing a somewhat dulled working edge. Striations were present on both lateral and/or distal edges with striations that are roughly parallel to the long axis of the artifact. There was no polish readily visible or evidence of thermal alteration. The distal tip of the artifact showed evidence of crushing and spalling which is believed to have been produced by a pounding and/or hammering motion as opposed to the lateral damage believed to have been produced by a sawing and/or scraping motion. The metric attributes are as follows: $T: 4.1 ; W: 22.5 ; L: 35.5$.

Specimen 2, Unit 16, Stratum 4 is a distal fragment of a biface that is triangular in planform, lenticular in cross section, and heavily patinated from weathering (Fig. 10, C). The proximal area exhibits a roll-snap break with the lateral edges exhibiting step and/or hinge-terminated flaking. Striations were visible on the scar ridges which were parallel to the long axis of the artifact. The metric attributes are as follows: $\mathrm{T}: 7.8 ; \mathrm{W}: 27.2 ; \mathrm{L}: 31.6$.

Specimen 3, Unit 16, Stratum 3 is a Perdiz point which is considered diagnostic of the Late Prehistoric era. It is made of dark chert and has been bifacially trimmed along both lateral edges (Fig. 10,d). The distal portion is missing with a roll-snap break present. The metric attributes are as follows:

$\mathrm{T}: 3.2 ; \mathrm{W}: 19.5 ; \mathrm{L}: 22.7$.

Specimen 4, Unit 16, Stratum 9 has a subtriangular planform and is biconvex in cross section. A roll-snap break is evident on the proximal edge with both lateral edges forming irregular edges produced by bifacial trimming. The scar ridges on these edges have been smoothed with the left lateral edge exhibiting the greatest amount of hinge-terminated flaking. No polish or striations were readily visible; there was no evidence of thermal alteration. The metric attributes are as follows: T: $7.0 ; \mathrm{W}: 25.1 ; \mathrm{L}: 24.0$.

Group II (eight specimens)

This group of artifacts consists of flakes that have been trimmed (both unifacially and bifacially) to form roughly ovate planforms or beaked planforms. 
Specimen 1, Unit 1, Stratum 9 is a distal fragment of an ovate planform flake. The proximal edge has a roll-snap break. Both lateral edges have been bifacially trimmed, producing regular edges; the artifact is biconvex in cross section. Edge damage is characterized by nicking and spalling on the scar ridges, producing a resultant dulling of the edge. Metric attributes are as follows: L: $7.0 ; W: 37.2 ; \mathrm{L}: 30.1$.

Specimen 2, Unit 16, Stratum 3 has an ovate planform which has been broken medially. Distally, there is a projection or beak that has step flaking on both lateral edges of the beak. Microwear analysis revealed that some striations were present on the scar ridges of the beak, parallel to the long axis of the artifact, which may have occurred in a punching and/or penetrating motion rather than a boring and/or screwing motion. Metric attributes are as follows: $T$ : $9.4 ; \mathrm{W}: 21.7$; L: 34.2 .

Specimen 3, Area A, Unit 2 has unifacial trimming evident on all edges with a roughly ovate planform which is high backed in cross section. The edges exhibit damage in the form of dulling of scar ridges that have been worn down rather than because of a crushing and/or pounding action. Metric attributes are as follows: $\mathrm{T}: 9.4 ; \mathrm{W}: 25.1 ; \mathrm{L}: 32.0$.

Specimen 4, Unit 6, Stratum 9 is a flake that has a platform angle consistent with that produced by a soft hammer blow. It is ovate in planform and biconvex in cross section. Both lateral edge's scar ridges are generally smoothed with spalling isolated principally to the ventral surface. These ridges have distinct striations that run parallel to the long axis of the artifact. Metric attributes are as follows: T: $5.1 ; \mathrm{W}: 18.1 ; \mathrm{L}: 37.5$.

Specimen 5, Area A, Unit 2 has been bifacially reduced and is believed to be a point preform. It is made of a poor quality chert that is closer to chalcedony than chert. There is no damage visible due to use-wear. This specimen has a beaked edge plan. Metric attributes are as follows: T: 9.0; W: $22.4 ; \mathrm{L}: 30.6$.

The metric attributes of Specimen 6 , Unit 16, Stratum 3 are as follows:

$\mathrm{T}:$ 7.2; W: $40.0 ; \mathrm{L}: 42.7$.

The metric attributes of Specimen 7, Area A, Unit 39 are as follows: T: 10.1; W: $28.5 ; \mathrm{L}: 27.6$.

The metric attributes of Specimen 8, Unit 16, Stratum 3 are as follows: T: $9.5 ; W: 19.5 ; \mathrm{L}: 34.7$.

Group III (six specimens)

This group consists of lenticular, concave-based specimens which have been termed mission points or Guerrero points (Hester 1977:9). This group contains the largest number of identifiable point forms and/or types and are consistent with those reported in Fox (1979). 
Specimen 1, Unit 16, Stratum 1 has regular lateral edges produced by bifacial trimming (Fig. 11, C). The scar ridges along these edges are generally smoothed with step and/or hinge-terminated flakes confined to the upper margins (distal) on both lateral edges. Striations, polish, or thermal alteration were not evident. Metric attributes are as follows: T: $2.48 ; \mathrm{W}: 14.5 ; \mathrm{L}: 21.1$; EA: $30^{\circ}$.

Specimen 2, Unit 16, Stratum 4 displays a roll-snap break on the distal tip. Step and/or hinge-terminated flake scars were evident on both lateral edges which form regular edges from bifacial trimming (Fig. 11,b). Striations (left lateral edge only) generally run parallel to the long axis of the artifact; polish was not present, nor were there any other scar ridges on the artifact. Metric attributes are as follows: T: $2.90 ; \mathrm{W}: 14.4 ; \mathrm{L}: 26.2$; EA: $33^{\circ}$.

Specimen 3, Unit 16, Stratum 3 has a planform and cross section that is consistent with the two previous artifacts (Fig. 11,e). Striations on lateral scar ridges had no specific directionality. From examination of the concave surface, there seems to be a general pattern of base-to-tip ordering in flake removals. Five flake scars on the left lateral edge had fissure marks that were removed from base-to-tip; the right lateral edge had four flake scars with identifiable fissure marks that likewise went from base-to-tip. Metric attributes are as follows: T: $2.59 ; \mathrm{W}: 17.1 ; \mathrm{L}: 17.3$; EA: $32^{\circ}$.

Specimen 4, Unit 16, Stratum 4 has a side profile consistent with one produced by a soft hammer blow for removals (Fig. 11,a). Bifacial trimming along both lateral edges has produced a regular edge, the ventral surface shows minimal trimming along the lateral edges, while the dorsal edge has been invasively trimmed twice the distance as the ventral surface. Edge damage consists of nibbling and nicking with most scar ridges still sharp. No polish or striations were readily apparent. Metric attributes are as follows: $T$ : 2.81 ; $:$ 18.4; L: $27.5 ; \mathrm{EA}: 35^{\circ}$.

Specimen 5, Area A, Unit 44 (Fig. 11,f) has a ro11-snap break on the distal edge and is more chalcedony than chert. The edge angle $\left(44^{\circ}\right)$ is the steepest among all the specimens. Dorsal and/or ventral surface scar ridges of this specimen, which are biconvex as opposed to lenticular in cross section, have some polish, while both lateral edges have no discernible polish; inferring that the artifact was used more in a puncturing and/or penetrating motion than sawing or pounding. Metric attributes are as follows: $T: 5.05 ; \mathrm{W}: 12.5$; L: 20.5 ; EA: $43^{\circ}$.

Specimen 6, Unit 17, Stratum 3 is made of translucent chert, triangular in planform, and lanceolate in cross section (Fig. 11,d). There is an impact burin present on the distal tip with hinge-terminated flake scars along both regular lateral edges. Flake scar patterning shows a base-to-tip reduction sequence on both lateral edges (dorsal). Metric attributes are as follows: $\mathrm{T}: 3.46 ; \mathrm{W}: 15.5 ; \mathrm{L}: 21.7$; EA: $34^{\circ}$.

Group IV (seven specimens)

This group consists of thin bifaces (less than $1.3 \mathrm{~cm}$ thick) that could not (morphologically) be placed in Groups I, II, or III. 


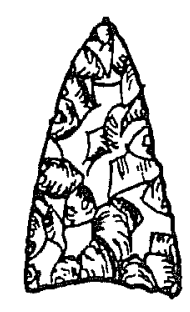

a
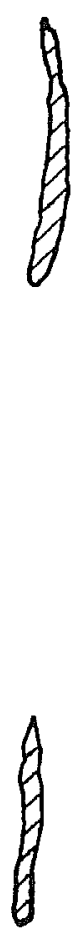

C

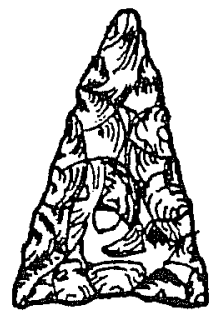

b
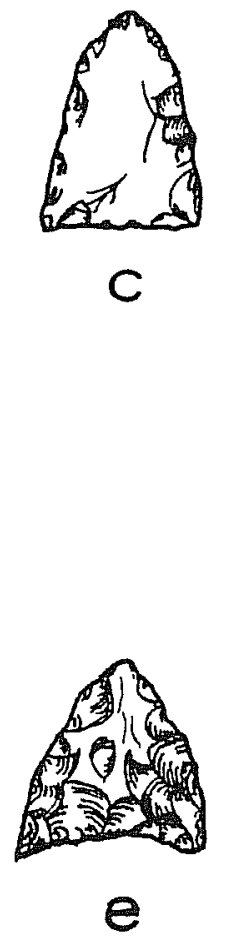
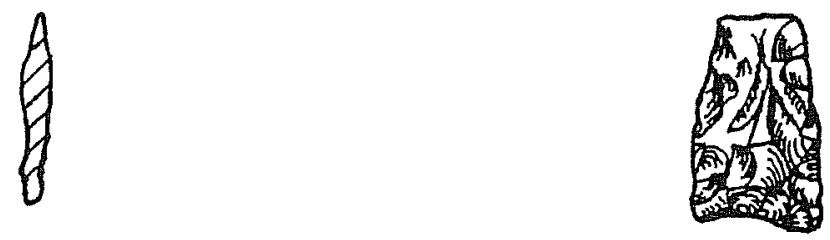

$f$

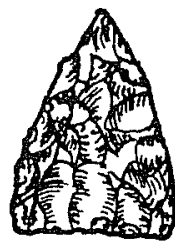

8

d

Figure 11. Guerrero Points: Thin Bifaces. Group III. a, Specimen 4, Unit 1E, Stratum 4; b, Specimen 2, Unit 16, Stratum 4; c, Specimen 1, Unit 16, Stratum 1; d, Specimen 6, Unit 1\%, Stratum 3; e, Specimen 3, linit 16, Stratum 3; $f$, Specimen 5, Area A, Unit 44. 
Specimen 1, Unit 16, Stratum 3 is a distal fragment with a roll-snap break on the proximal edge. Lateral edges form regular edges produced by bifacial trimming. This specimen is triangular in planform and biconvex in cross section. Metric attributes are as follows: T: $2.7 ; \mathrm{W}: 10.6 ; \mathrm{L}: 11.7$.

Specimen 2, Unit 16, Stratum 2 is a distal fragment with a roll-snap break present on the proximal edge. The specimen is triangular in planform and lenticular in cross section. The dorsal surface has one major arrise formed by previous flake removals and retains a relatively sharp edge. Metric attributes are as follows: T: 4.2; W: 16.5; L: 16.1 .

Specimen 3, Unit 19, Level 1 is also a distal fragment of a point that is triangular in planform, but biconvex in cross section. The right lateral edge exhibits the most edge damage, characterized by hinge-terminated flake scars. Both lateral edges form regular edges produced by bifacial trimming. Metric attributes are as follows: T: 5.1 ; W: 25.1 ; L: 29.8.

Specimen 4, Unit 6, Stratum 9 is a medial fragment of a point that exhibits rol1-snap breaks on both the distal and proximal margins of the artifact. Polish and striations are present on the scar ridges along both lateral edges which generally run parallel to the long axis of the artifact. The proximal margin shows evidence of utilization after it was broken with step and/or hinge-terminated flaking. Metric attributes are as follows: T: 8.0; W: 23.5; $\mathrm{L}: 35.1$.

Specimen 5, Area A, Unit 3 has a rectangular planform and is low backed in cross section. The distal edge angle is $46^{\circ}$ which forms a regular edge with some step flaking present. The left lateral edge exhibits more wear than the right lateral edge and is characterized by hinge-terminated flakes, while the right lateral edge has damage primarily due to spalling with some hingeterminated flakes. Striations were noted along both lateral edges which generally ran parallel to the artifact's long axis. Metric attributes are as fol1ows: $T$ : 12.2; W: $25.1 ; \mathrm{L}$ : 49.5 .

Specimen 6, Area A, Unit 2 has a large patch of cortex on the dorsal surface and is more chalcedony than chert. The edge angle approaches $60^{\circ}$, producing we11-supported working edges. Scar ridges are almost worn away from use, producing a dull edge. Metric attributes are as follows: T: 11.6; W: 21.5; L: 35.6 .

Specimen 7, Unit 6, Stratum 9 is also more chalcedony than chert with bifacial trimming confined to the left lateral edge; the right lateral edge has been unifacially trimmed. The specimen has an irregular planform, has little to no damage to the lateral edges, and the distal end exhibits some step and/or hinge flaking. Metric attributes are as follows: T: 9.8; W: 31.7 ; L: 42.5 .

Gunflints (14 specimens; Fig. 12,a-e)

Most of the gunflints are square to rectangular in planform with a flat surface either on the dorsal or ventral surface. Only one of the artifacts is not 


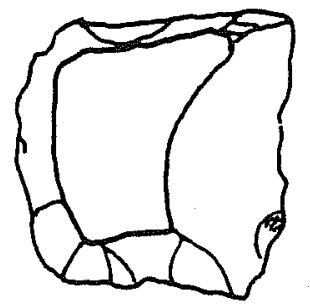

a

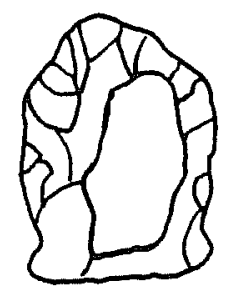

C

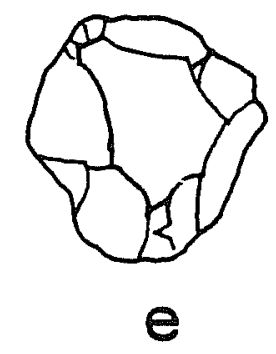

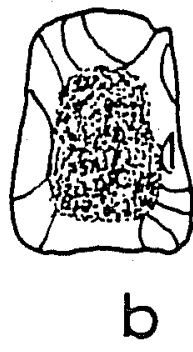

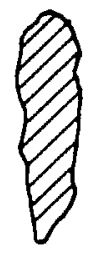

$b$
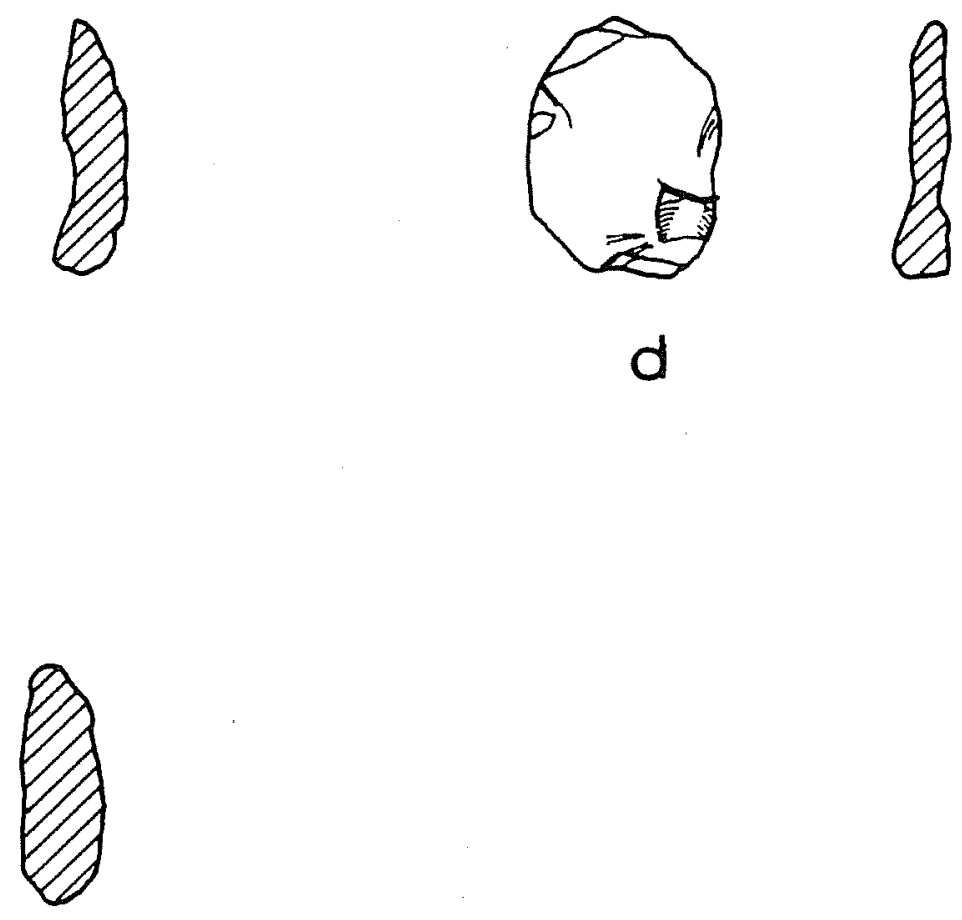

Figure 12. Gunjlints. a, Specimen 11, Unit 6, Stratum 9; b, Specimen 14, Unit 16, Stratum 6; c, Specimen 12, Unit 16, Stratum 9; d, Specimen 4, Area A, Unit 2; e, Specimen 3 , Area $A$, Unit 2. 
consistent with the color range of chert occurring locally at the site; it is honey colored.

Metric attributes are as follows:

\section{Artifact Provenience Length Width Thickness Edge Angle}

Specimen 1, Unit 16, Stratum 2

Specimen 2, Area A, Unit 39

Specimen 3, Unit 16, Stratum 6

Specimen 4, Area A, Unit 2

Specimen 5, Unit 16, Stratum 4

Specimen 6, Unit 16, Stratum 10

Specimen 7, Unit 16, Stratum 4

Specimen 8, Area A, Unit 2

Specimen 9, Unit BD, Stratum 11

Specimen 10, Area A, Unit 2

Specimen 11, Unit 6, Stratum 9

Specimen 12, Unit 16, Stratum 9

Specimen 13, Area A, Unit 2

Specimen 14, Unit 16, Stratum 6

21.6

21.2

21.4

32.0

30.5

17.7

25.6

22.0

28.1

22.6

28.2

26.5

27.0

24.1
20.2

20.1

12.0

20.0

2]. 5

18.0

19.2

18.7

22.6

24.1

27.4

20.1

19.1

12.7
8.3

7.0

8.1

8.2

7.8

8.9

6.9

7.4

5.1

8.9

8.8

7.0

6.1

7.1 $58-60^{\circ}$

$50-55^{\circ}$

$65-70^{\circ}$

$52-58^{\circ}$

$47-49^{\circ}$

$40-55^{\circ}$

$37-45^{\circ}$

$64-67^{\circ}$

$35-41^{\circ}$

$65-72^{\circ}$

$72-79^{\circ}$

$42-52^{\circ}$

$42-58^{\circ}$

$53-57^{\circ}$

Mean

24.9

18.3

7.5

$51^{\circ}$

Discussion of Horizontal Distribution

The greatest number of 1 ithic materials recovered during the second season of field work was from the trash pit (Unit 16, see Table 2) and comprises $48.5 \%$ of the entire assemblage. Unit 16 was capped with fill dirt and is considered to be pre-1780 (James Ivey, personal communications). Small intrusive pits were noted within Unit 16, which may be the result of treasure hunters. Unit 16 provides a stratified look into the types and range of activities present at Rancho de las Cabras during its earliest occupation. Cortex platform secondary flakes were preferred as unmodified tools by a ratio of $3: 1: 1$ over single or multiple facet secondary flakes while a ratio of $3: 4: 4$ exists for trimmed (prepared tools) secondary flakes. A 2:1 ratio exists among primary (unmodified and modified) flakes, while a $2: 1$ ratio also exists among unmodified and modified tertiary flakes. There is a distinct preference for use of secondary flakes as unprepared tools, while primary flakes are about 1:1 for unmodified and modified tools; tertiary flakes have a ratio of $2: 1$ for trimming versus utilization as unprepared tools.

From Unit 3 came $9.4 \%$ of the lithic assemblage. Most of these artifacts were surface collections and are believed to be the result of random factors and not cultural factors that may have been present in this area (James Ivey, personal communication). 


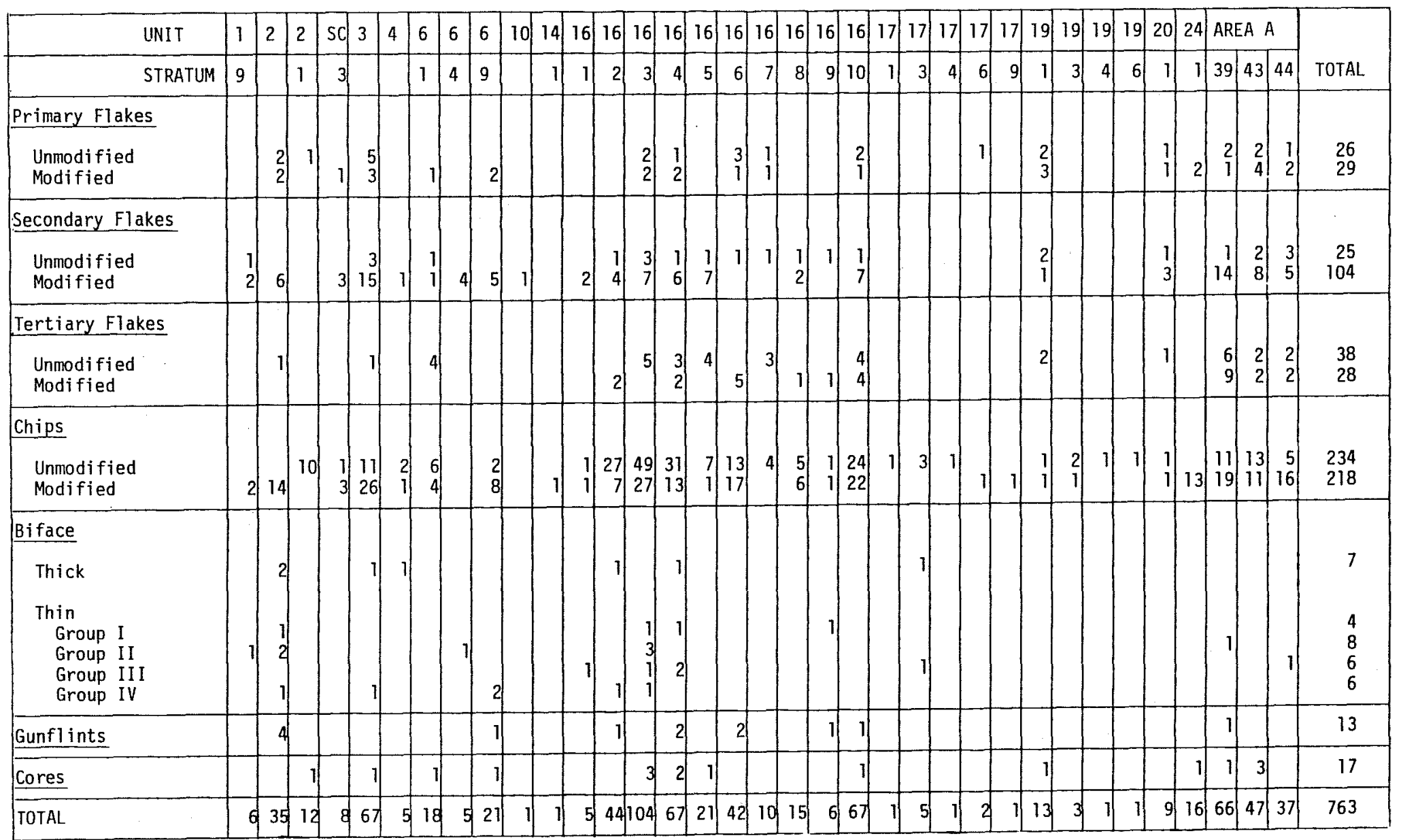


Area A (Strata 39, 43, 44; Units 10 and 11) contains a jacal area with distinct occupation levels. Units 10 and 11 are hearths, while Strata 43 and 44 are alike but separated by a row of post holes delineating what are believed to be distinct living quarters. Stratum 39 consists of the rest of the area near Strata 43 and 44 within Area A.

The surface of Strata 43 and 44 are thought to be the loci of multiple events (i.e., food preparation, sleeping) and consists of fine horizontal components (lenses). Horizontal distribution of recovered artifacts infers that the strata have roughly equivalent activities with no specialization of one activity to a specific stratum.

Unit 6 comprised $5.5 \%$ of the lithics recovered and is located inside and some distance from the west wa11; a 11 other units discussed (except Unit 16) were in close proximity to the walls of the ranch.

Summary

The lifetime of the site of Rancho de las Cabras was less than 50 years with little change noted during the period. The lithic industry present centers on locally acquired materials from the nearby San Antonio River. The Rancho may be considered to have been a small village with pastoral-supported activities combined with hunting and gathering of seasonal products. Future excavations should include extensive efforts to locate a garden or agricultural area outside the architectural remains.

In general, the 1 ithic assemblage from this Spanish Colonial period site is not radically different from other prehistoric assemblages in south Texas. Almost all tools identified were produced by flaking technologies with blade technology absent.

The primary types of edge damage noted from utilization appear to have been produced in a cutting and/or sawing motion with few artifacts displaying damage consistent with a pounding and/or hammering motion. Many of the lithic forms present, which might normally be considered as prehistoric, indicate that they were still being used and manufactured while living at the missions. The most notable shift (and the only one noted) in lithic form is the presence of the mission point (Guerrero point), which was also present in the Prehistoric period, as the preferred trajectory in the projectile point technology. 
Clark, J.W., Jr.

1978 Mission San Jose y San Miguel de Aguayo: Archeological Investigations, December 1974. Office of the State Archeoligist, Texas Historical Commission, Report 29.

Fox, D. E.

1979 The Lithic Artifacts of Indians at Spanish Colonial Missions, San Antonio, Texas. Center for Archacological Research, The. University of Texas at San Antonio, Special Report 8.

Hester, T. R.

1977 The Lithic Technology of Mission Indians in Texas and Northeast Mexico. Lithic Technology 6(1-2).

Hester, T. R., D. Gilbow, and A. Albee

1973 A Functional Analysis of Clear Fork Artifacts from the Rio Grande Plain of Texas. American Antiquity 38(1):90-96.

Odel1, G. H.

1981 The Mechanics of Use-Breakage of Stone Tools: Some Testable Hypotheses. Journal of Field Archaeology 8(2):198-209.

Schuetz, M. K.

1968 The History and Archeology of Mission San Juan Capistrano, San Antonio, Texas (Vol. 1). Historical Documentation and Description of Structures. State Building Commission Archeological Program, Report 11.

1969 The History and Archeology of Mission San Juan Capistrano, San Antonio, Texas (Vol.2). Description of the Artifacts and EthnoHistory of Coahuiltecan Indians. State Building Commission Archeological Program, Report 11.

1970 Excavations of a Section of the Acequia Madre in Bexar County, Texas, and Archeological Investigations at Mission San Jose in Apri1, 1968. Texas Historical Survey Committee, Archeological Report 19.

1973 Archeological Investigations at Mission San Antonio de Valero, the Second Patio. Unpublished manuscript. On file, Office of the State Archeologist, Texas Historical Commission, Austin, Texas. 
Scurlock, D. and D. E. Fox

1977 An Archeological Investigation at Mission Concepción, San Antonio, Texas. Office of the State Archeologist, Texas Historical Commission, Report 28.

Scurlock, D. and T. P. Powers, Jr.

1975 Interim Report for Mission Concepción (Archeological Investigations), San Antonio, Bexar Co., Texas. Office of the State Archeologist, Texas Historical Commission, Special Report 7. 
